\title{
Petrological, Physico-Chemical and Mechanical Characterization of the Topomorphic Vertisols from the Sudano-Sahelian Region of North Cameroon
}

\author{
Primus Azinwi Tamfuh ${ }^{1}$, Emmanuel Djoufac Woumfo $^{2}$, Dieudonné Bitom ${ }^{*}, 1$ and Daniel Njopwouo ${ }^{2}$ \\ ${ }^{1}$ Laboratoire de Pédologie, Faculté des Sciences, Université de Yaoundé 1, B.P. 812, Yaoundé, Cameroun \\ ${ }^{2}$ Laboratoire de Physico-Chimie des Matériaux Minéraux, Faculte des Sciences, Universite de Yaoundé 1, B.P. 812, \\ Yaoundé, Cameroun
}

\begin{abstract}
In Cameroon, topomorphic vertisols are widespread in the Sudano-sahelian zone above latitude $9^{\circ} \mathrm{N}$. With a depth of about 2 to $2.5 \mathrm{~m}$ above the water table, these soils show four main horizons from bottom to top: a dark grey horizon with hydromorphic patches $\left(\mathrm{B}_{3 \mathrm{~g}}\right)$, dark grey horizon $\left(\mathrm{B}_{21}\right)$, dark grey horizon with slickensides $\left(\mathrm{B}_{1}\right)$ and a surficial grey humiferous horizon $\left(\mathrm{A}_{1}\right)$ with desiccation cracks. Also, they show a heavy clayey texture, very massive structure, high bulk density, very low porosity and a high compacity. The microfabric of the soils is marked by abundant plasmas, isotic at the surface but birefringent at depth, with numerous stress cutans. The microscopic analysis of heavy minerals reveals the presence of magmatic and metamorphic minerals from the upper part of the watershed. Quartz grains are mainly angular to sub-angular revealing short fluvial transport distance. The vertisols are thus formed from recent alluvial deposits from weathering, erosion and deposition of rocks from upper parts of the watershed. Physico-chemically, the studied soils are characterized by high cation exchange capacity $(26-42 \mathrm{meq} / 100 \mathrm{~g})$, high sum of bases $(74.30-94.23$ meq/100g), high base saturation, low organic carbon and a very high $\mathrm{C} / \mathrm{N}$ ratio. Geochemically, Si and $\mathrm{Al}$ are the dominant elements, characterised by a Si/Al ratio range of 2.27 and 2.94. According to this rate, 2/1 clay minerals, namely smectite, are predominant and their presence confirms the shrink-swell behaviour of the soils. Total base concentrations are high and could be related to the contrasted climate and the low landscape position. Mechanical analyses revealed very high liquid limits (36-46\%), low plastic limits (10-17\%), high plasticity indices and high shrinkage limits that permit to classify those soils as medium to high plasticity inorganic clays. Those soils could be potentially useful in many domains like the chemical industry, pharmaceutics, petroleum industry, agronomy or environmental protection.
\end{abstract}

Keywords: Topomorphic vertisols, smectite, Benue watershed, North Cameroon, Africa.

\section{INTRODUCTION}

Vertisols constitute a group of soils that occur mainly in hot environments with distinct alternating wet and dry seasons [1-3]. They are characterised by at least $30 \%$ clay fraction, the abundance of smectitic swelling clay minerals [1-6], a high cation exchange capacity $(20-45 \mathrm{meq} / 100 \mathrm{~g}$ of soil) and a high base saturation (80-100\%) [5-9]. The extensive swelling and shrinking upon wetting and drying is the major characteristic of these soils [3, 4]. Vertisols cover $2.42 \%$ of ice-free land $\left(3.16\right.$ million $\left.\mathrm{km}^{2}\right)$, occurring mainly in the intertropical zone [10]. Based on their smectite content, these soils present numerous interesting economic potentials in the chemical industry, pharmaceutics, agronomy and environmental protection [5, 6, 11]. Two main types of vertisols can be distinguished: lithomorphic vertisols and topomorphic vertisols $[1,12,13]$. Lithomorphic vertisols are formed on various parent rocks whose weathering generates base-rich environments favourable for smectite synthesis, while topomorphic vertisols are formed mainly in favour of low landscape positions which favour the accumulation of bases $[1,12,13]$. The latter cover very

*Address correspondence to this author at the Laboratoire de Pédologie, Faculté des Sciences, Université de Yaoundé 1, B.P. 812, Yaoundé, Cameroun.; Tel: (237) 993214 55; E-mail: bitomoyono@yahoo.fr extensive continuous surface areas of the globe, while the former have limited geographical extensions and occur mainly in specific islands and volcanic regions [1]. Many authors have studied topomorphic vertisols based on their nature, inventory and spatial distribution $[1,5,8,9,15-23]$, their mineralogical composition $[5,24,25]$, their geotechnical properties [4, 26, 27], agronomic characteristics $[19,28-30]$ and their adsorptive properties as bleaching earth $[5,31]$. In the Benue watershed of North Cameroon, topomorphic vertisols are very widespread and associated with other important soil groups, which occupy much higher landscape positions like ferrallitic, ferruginous and fersiallitic soils. In the Benue alluvial terrace, vertisols are the most abundant soil groups and are associated with raw mineral, mollic, planosolic and hydromorphic soils [2, 17, $20,21]$. In this plain, topomorphic vertisols are highly sought by the local inhabitants for their high, although seasonal, fertility $[2,18,20,21]$. However, reconnaissance data on topomorphic vertisols, notably on the petrological, mechanical and physico-chemical aspects, are insufficient to allow an efficient exploitation of the soils. The main goal of the present study is therefore the characterization of topomorphic vertisols of North Cameroon from a petrological, mechanical and physico-chemical point of view. Thus, it would be possible to provide soil information 
to use especially in agricultural purposes, farm planning and other engineering practices such as building, roads, etc.

The study's interest is both fundamental in order to supplement the available database on vertisols and applied in view of better management and protection/conservation of these soils.

\section{ENVIRONMENTAL SETTING}

The Upper Benue watershed is located between latitudes $6^{\circ} 43^{\prime}$ and $10^{\circ} 45^{\prime} \mathrm{N}$, and longitudes $11^{\circ} 41^{\prime}$ and $15^{\circ} 40^{\prime} \mathrm{E}$ (Fig. 1). With a total surface area of $95.000 \mathrm{~km}^{2}$, it is unequally distributed between three countries including Cameroon $\left(75.000 \mathrm{~km}^{2}\right)$, Chad $\left(18.000 \mathrm{~km}^{2}\right)$ and Nigeria $\left(2000 \mathrm{~km}^{2}\right)$.

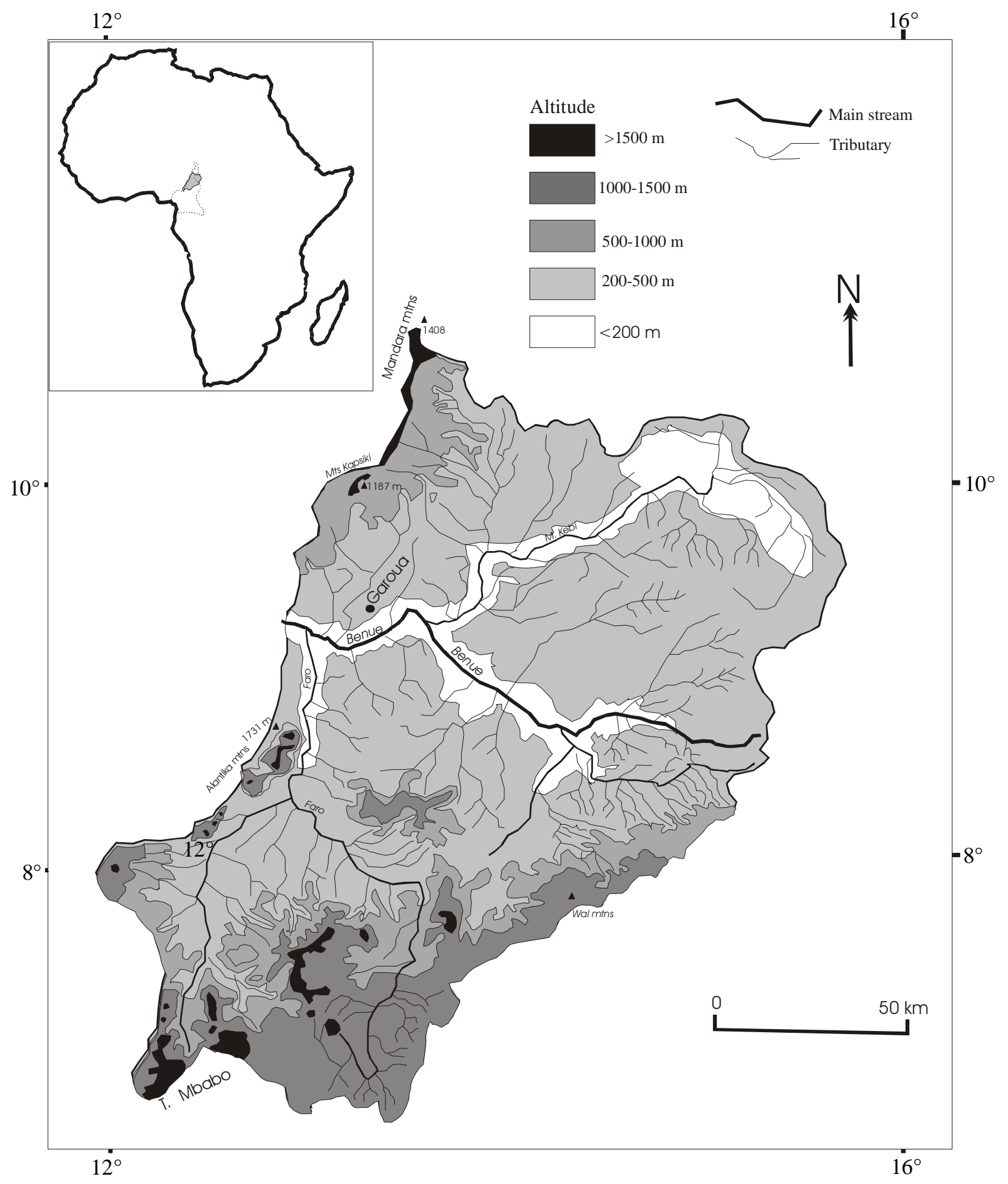

Fig. (1). Location and oro-hydographic map of the Benue watershed [32]. 
This watershed is a prolongation of the Niger basin whose total surface area is $340.000 \mathrm{~km}^{2}$. It is under a tropical climate with two contrasted seasons: a humid one from May to October, and a dry one from November to April; total yearly precipitation varies between 900 and $1500 \mathrm{~mm}$, mean annual temperature is $28^{\circ} \mathrm{C}$ and average annual amplitude is $6.4^{\circ} \mathrm{C}$ typical of a classical Sudanian climate [33]. Streams, mainly seasonal, take their rise either on the Mandara Mountains, the Adamawa highlands or the Logone plain. The Benue River, the principal collector, takes its rise on the Adamawa highlands and together with its numerous tributaries constitutes a dense and dendritic drainage network [32]. The vegetation of the watershed is the Sudanian savannah domain with numerous transitions from the Sudano-guinean type on the Adamawa Plateau, a Sudano-sahelian seasonally flooded prairie on the Benue floodplains, altitude Sudanian savannah on the Mandara Mountains and the scanty wood savannah on the rest of the territory [34].

The distribution of soils is conditioned by climate, parent rock and topography [8]. The major soil groups are raw mineral/lightly evolved soils, hydromorphic soils, ferrallitic soils, vertisols, halomorphic soils, ferruginous soils and fersiallitic soils $[17,18]$. The ferruginous soils cover a large surface area from latitude $8^{\circ} \mathrm{N}$ to the extreme north of the watershed. They constitute the most abundant soil unit in the Benue watershed covering about $40 \%$ of total land area. They form on the granito-gneissic basement and on the Cretaceous sandstones and they are composed of a mixture of kaolinite and smectite associated with sesqui-oxides of iron [1]. Raw minerals/lightly evolved soils, the second most abundant soil type (about $30 \%$ ), develop on weathering pediments, colluvial and alluvial materials, inselbergs or chaotic landscapes on hillslopes. They are principally located on the Mandara Mountains and south of the Benue River as numerous isolated bands. They show relatively thin profiles (less than 1 to $2 \mathrm{~m}$ ) with a brown surface colour [1, 13]. Vertisols represent about 25 to $30 \%$ of the total surface; they are very dark-coloured soils with a heavy clayey texture, rich in swelling smectitic minerals and poor in iron. Their surfaces show numerous desiccation cracks. They form mainly on alluvial and colluvial materials [8, 18]. Lithomorphic/pediplain vertisols are far less abundant and form from the weathering of diverse parent rocks, which include amphibolites, granites, etc. They are represented at the foot of the Mandara Mountains [8, 1]. Hydromorphic soils are also widely distributed, representing about 10 to $15 \%$ of the total surface area of North Cameroon. They cover vast areas in the Benue trough in association with topomorphic vertisols [18]. They are dark colored soils with thin profiles, with numerous yellowish red patches. Halomorphic soils represent less than $10 \%$ of the North Cameroon studied zone; they also show shallow profiles and vegetation cover is rare. They are well represented inside the Faro basin at the point where the Benue enters Nigeria and they are either associated with lightly evolved soils, topomorphic vertisols or hydromorphic soils $[17,18]$. Fersiallitic soils have a limited geographical extension (about 5\%). They are found in the north of the Benue trough and at the foot of the Mandara Mountains as isolated bodies [18]. They form on volcano-sedimentary rocks (andesites, rhyo-dacites, diorites, etc.) and they show thin profiles (about $1 \mathrm{~m}$ ) and a brown to reddish colour. Ferrallitic soils are represented in the extreme south of the Benue watershed precisely on the Adamawa highlands around the Vina, Far and Mbere watersheds. They are formed on various parent materials as basalts, granites, gneiss, etc. The ferrallitic soils on basalts show a yellowish brown to reddish brown colour, a lumpy texture and are lightly permeable. Those that formed on acid rocks (granites, etc.) are grey, very sandy at the surface and very permeable $[8,16]$.

Geomorphologically, the Benue watershed is characterised by very varied and uneven high landscapes on both sides of the Benue trough with Tchabal Mbabo (2460 $\mathrm{m})$ as the highest point. The Benue trough is the eastward extension in North Cameroon of the Yola branch of the Benue trough in Nigeria [35]. It is a rift that formed within the Meso- to Neoproterozoic granitic-gneissic basement and is entirely filled with continental sediments (sandstones) of the Middle to Upper Cretaceous age $[36,37]$. The Benue trough is related to the opening of the Gulf of Guinea [38]. These continental deposits are principally composed of sandstone banks and clay lenses [36]. They differentiate into the Garoua sandstones in the western part of the Benue trough and Benue sandstones in the east of Garoua (Fig. 2). The former is pierced by numerous Tertiary volcanic intrusions composed mainly of trachytes associated with basalts, hawaiites, mugearites, rhyolites and phonolites [39, 40]. The palaeontological correlations of the Garoua and Benue sandstones indicate that they belong to the same sedimentary set, possibly contemporaneous with a lateral passage of facies from one to another [36]. They lie discordantly on undifferentiated Precambrian bedrock composed of granite, gneiss, schist, micaceous quartzite and feldspathic amphibolites. The structural evolution of the Benue trough has been deciphered: its opening occurred during the Neocomian-Lower Aptian, and its subsidence and partial infilling by conglomerates and sandstones took place in the Cretaceous [35]. Post-Cretaceous faulting affected these continental sediments and favoured the later intrusive volcanic activity [41]. New K-Ar age determinations revealed that the whole volcanic series was emplaced at $37 \pm 2 \mathrm{Ma}$ [39]. Close to the Benue River and its tributaries, the sandstone complex is overlain by alluvial deposits, about $35 \mathrm{~m}$ thick, composed of sands, gravels and clays [2, 36, 37]. Those alluvial deposits are constituted by recent floodplain deposits (clay, sand and silt) formed on the 11.000 years old terrace. Both ancient and recent deposits are rich in weatherable primary minerals (biotite, feldspars, amphiboles, hornblende, etc.) and swelling clays (smectite) characteristic of downslope accumulations and authigenesis [16, 18]. Overall, the ancient terrace shows three overlapping series that include planosolic sandy clays at the base, vertisolic clays at the centre, and finally calcareous silts and ferruginous sands at the top $[2,18]$. Recent data reveals they resulted from an intense period of erosion in the Tertiary, followed by infilling of all depressions and valleys probably due to rise in base level at the beginning of the Quaternary [42]. The Benue River terrace shows a number of geomorphic entities which include [18] (Fig. 3): (a) the embankment, located 2 to $7 \mathrm{~m}$ above the river thalweg, 400 $\mathrm{m}$ by $400 \mathrm{~m}$ wide, incised into narrow ridges and covered by 


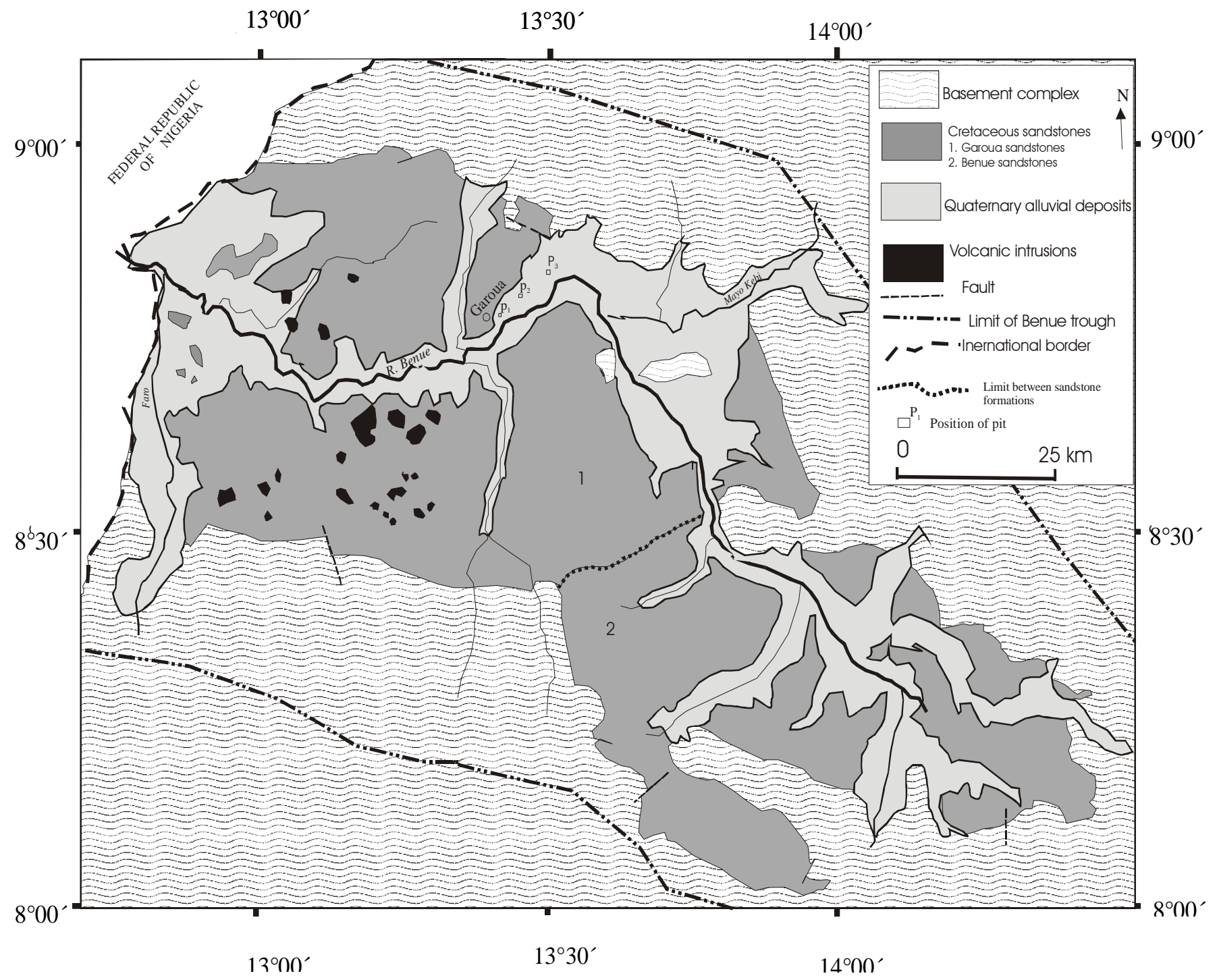

Fig. (2). Geological map of the Benue trough of North Cameroon [36, 37, 39] and location of sampling sites.

lightly evolved soils, well drained with a coarse grained texture. The vegetation cover of this entity is a strongly anthropogenised sparse forest; (b) the levee, which forms a continuum with the embankment, is 2 to $6 \mathrm{~m}$ above the thalweg and $400-800 \mathrm{~m}$ wide, regular slope of 0.4 to $0.6 \%$, lightly deformed by parallel undulations imposed by ancient beams of the embankment which were entirely eroded. The soils are moderately hydromorphic mollic soils, with a fine structure and a silty clayey texture, meanwhile the vegetation is a sparse forest-savannah transition; (c) footslope of levee, which is flat, with the main soils being planosolic type having surficial desiccation cracks and a middle whitish horizon with fine, pure, angular quartz grains. The vegetation is savannah (d) the overflowing plain, which forms a continuum with the levee, is characterised by transverse slopes $(0.2 \%)$, a width of $1-4 \mathrm{~km}$ and an elevation of 2 to $4 \mathrm{~m}$ above the river thalweg. Soils are brown hydromorphic soils, which are well-drained, clayey silty, thick $(>3 \mathrm{~m})$ and chemically very rich. The vegetation cover is a strongly anthropogenised savannah with crops (rice, wheat, cotton, sorghum); (e) the overflowing trough, at the footslope of the overflowing plain, is flat and enclosed; this configuration favours a drop in river speed, overflowing and subsequent deposition of its load to continuously renew alluvial deposits of the floodplain. The main soils are topomorphic vertisols and the vegetation is savannah and crops (mouskwari and rice); (f) the decantation troughs, which occupy the lowest landscape positions of the alluvial terrace, are marshy, flat and rise $2 \mathrm{~m}$ above the river thalweg. The soils are vertic gleys with surficial desiccation cracks; they are very light and very clayey. A ground water resource underlies the alluvial deposits, the sandstones and the weathered basement [42]. At the beginning of the dry season, this water resource appears only at the footslope of the levee and its roof is less than $4 \mathrm{~m}$ deep. Its lateral extension is variable from one stream to another and along the same stream. It is less than $3 \mathrm{~km}$ wide on either sides of streams and becomes shallower with increasing distance away from the stream bed. Chemical and isotopic data provided evidence of two distinct water systems in the aquifers: a shallow ground water system and a deep one. The former, characterised by dilute waters, were charged by direct infiltration of rainwater through some unconfined zones of the aquifer, and by lateral infiltration of free surface 


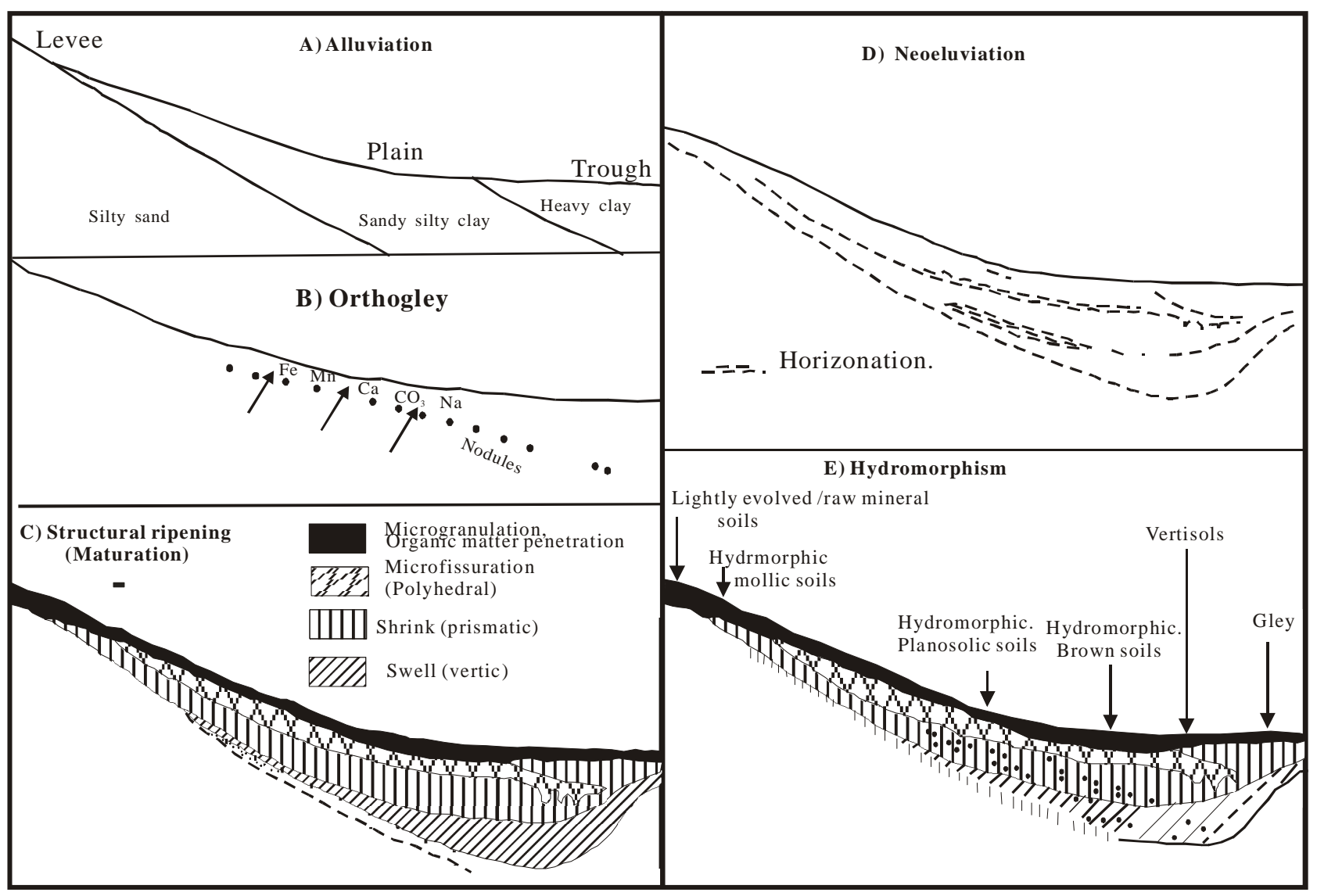

Fig. (3). Schematic toposequence showing the stages of soil formation and evolution on the Benue River alluvial deposits [18].

water. The deep ground water system reflects a mixture between superficial and old ground water resources that were probably recharged under more humid conditions than at present [43]. Chemically, those ground water resources were slightly mineralized, basic, carbonate, calcic or even rarely sodic and phosphatic in nature [43].

\section{MATERIALS AND METHODS}

\subsection{Materials}

In the course of the present study, three main sites (Garoua Brasseries, Poumpoumré and Bounguel) were selected along the Benue seasonally flooded plain $(<200 \mathrm{~m}$ altitude) where vertisols were located (Fig. 2). For each site, one vertical profile was studied in detail.

Profile $\mathrm{P}_{1}$ was dug at the east of Garoua Brasseries on latitude $9^{\circ} 15^{\prime} \mathrm{N}$, longitude $13^{\circ} 24^{\prime} \mathrm{E}$ and an elevation of 175 m. Slope gradient was $0.6 \%$, current land use was for sorghum cultivation without irrigation. This pit was $2.5 \mathrm{~m}$ thick above the watertable and presented four main horizons, which included from bottom to top (Fig. 4), (a) the $\mathrm{B}_{3} \mathrm{~g}$ (150-250 cm), very dark grey (10YR3/1) horizon, clayey and compact, with a massive blocky structure, $5 \%$ reddish yellow (7.5YR6/8) 1-2 mm size patches, occurring mainly along fissures. In the field, this horizon was waterlogged at its base and appeared muddy on sampling. Transition with the overlying horizon was gradual, marked by a reduction in intensity of the dark colour. (b) the $\mathrm{B}_{21}(100-150 \mathrm{~cm})$, dark grey $(10 \mathrm{YR} 4 / 1)$ horizon, with clayey texture and massive structure; it was very compact and reddish yellow (7.5YR6/8) patches (5\%) were still present. Transition to the next horizon was very gradual, marked by the appearance of slickensides. (c) the $\mathrm{B}_{1}(30-100 \mathrm{~cm})$, dark grey $(10 \mathrm{YR} 4 / 1)$ horizon was characterised by numerous smooth and shiny surfaces called slickensides that separated different blocks; their diameters varied between 5 and $10 \mathrm{~cm}$. Transition to the surface horizon was gradual, marked by the appearance of cracks and slight brightening of soil colour. (d) the $A_{1}$ $(0-30 \mathrm{~cm})$, grey $(10 \mathrm{YR} / 1)$ horizon, which presented more abundant yellowish red patches $(10 \%)$ and more abundant voids $(20 \%)$. The presence of numerous $1-2 \mathrm{~cm}$ wide and $30-35 \mathrm{~cm}$ deep cracks separated different polyhedral blocks of 20 - $40 \mathrm{~cm}$ diameter, defining a strongly expressed polyhedral macrostructure (Fig. 4). Few dark brown dry leaves and roots were present, completely mixed up with the clayey matrix. All the above horizons were very hard when dry.

Profile $\mathrm{P}_{2}$ was implanted at Poumpoumré on latitude $9^{\circ} 20^{\prime} \mathrm{N}$, longitude $13^{\circ} 28^{\prime} \mathrm{E}$ and an altitude of $180 \mathrm{~m}$, on a sub-horizontal to flat plain whose gradient was about $0.3 \%$. The land use was for sorghum cultivation without irrigation. This profile was limited to $2.1 \mathrm{~m}$ depth. It showed three horizons above the watertable which included the $B_{21}$ $(210-110 \mathrm{~cm})$ horizon, the $\mathrm{B}_{1}(40-110 \mathrm{~cm})$ horizon and the $\mathrm{A}_{1}$ 


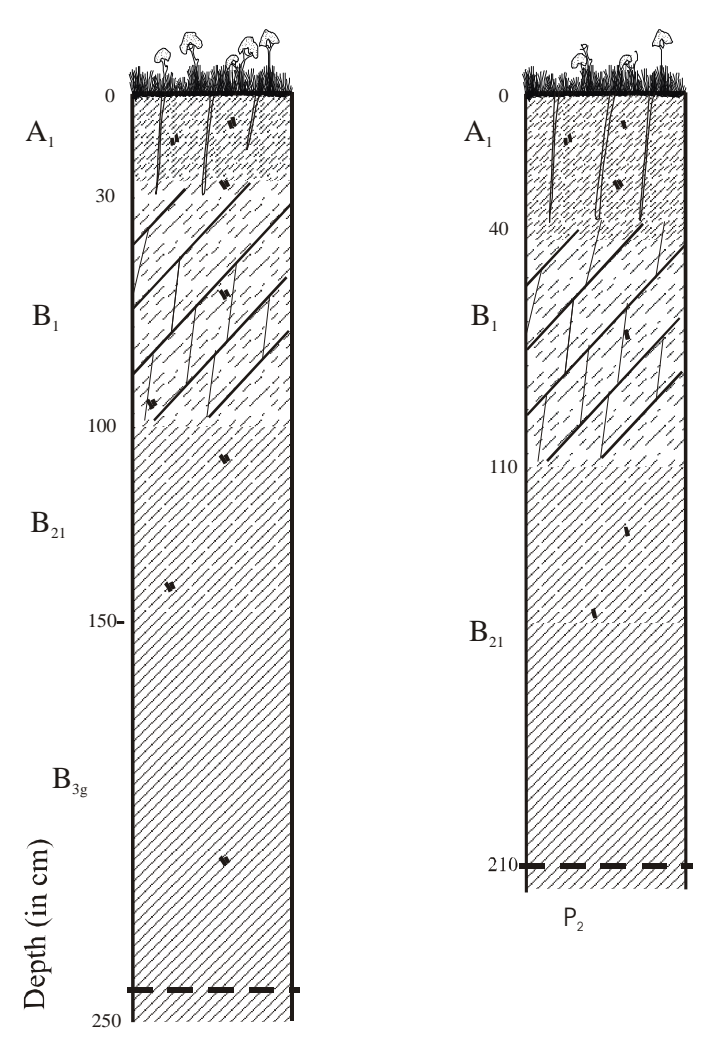

$\mathrm{P}_{1}$

(A)
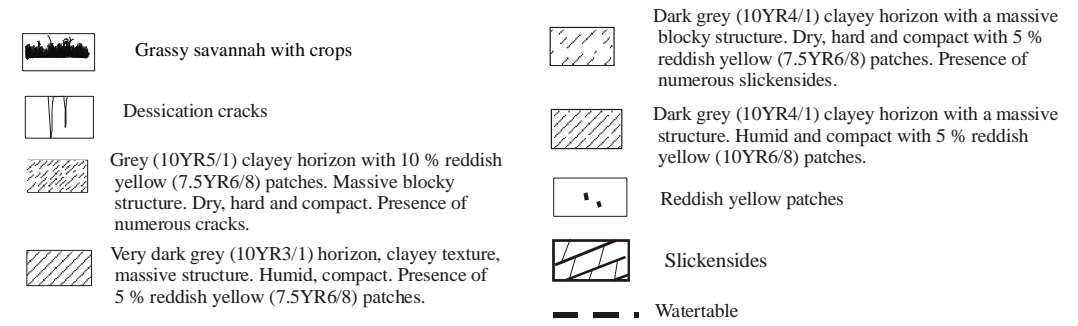

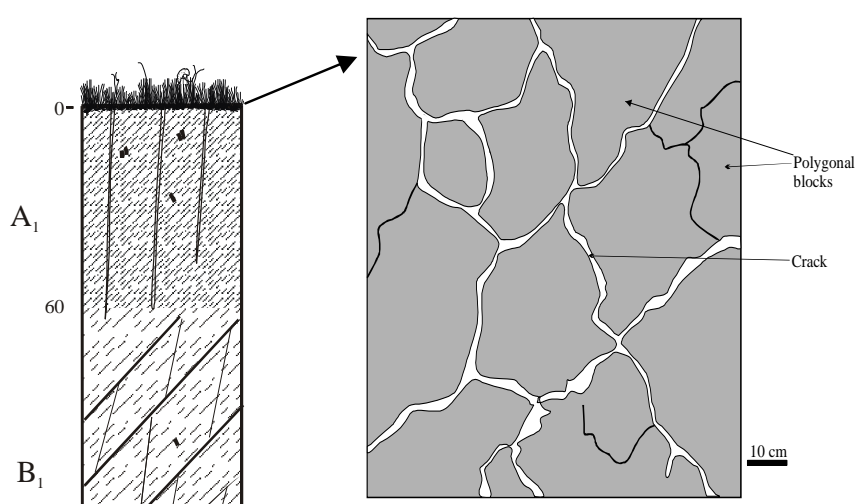

(B)

Fig. (4). Morphological organisation of the studied vertisol profiles (A) and surface view of desiccation cracks (B).

(0-40 cm) horizon (Fig. 4). Those horizons were morphologically identical to those of profile $\mathrm{P}_{1}$.

Profile $\mathrm{P}_{3}$ was dug at Bounguel at latitude $9^{\circ} 24^{\prime} \mathrm{N}$, longitude $13^{\circ} 31^{\prime} \mathrm{E}$ and at an elevation of $178 \mathrm{~m}$. Slope gradient was about $2 \%$, land use was for sorghum plantation without irrigation. It was limited at $2.3 \mathrm{~m}$ depth (watertable). This profile was morphologically similar to the previous one (Fig. 4).

Overall, the studied soil profiles were characterized by a dark colour, a clayey texture, massive structure, low porosity, high compacity and deep open surficial desiccation cracks, but also by the development of frictional surfaces (slickensides) in the middle part of the profile. Globally, the different materials of the profiles were only lightly differentiated from one another and differed from each other only by light modifications of their colour and structure. Finally, undisturbed samples were collected for thin sections observations and disturbed ones for the rest of the laboratory analyses.

\subsection{Methodology and Analytics}

In the laboratory, the soil samples were prepared depending on the type of analysis envisaged (air-dried, crushed with mortar and pestle, sieved to remove coarse fragments, etc.). Five types of analyses were performed: microscopic, mineralogical, geochemical, mechanical and physico-chemical analyses.

Microscopic analyses with a polarising microscope were performed on thin sections which were cut after impregnation with resin. Heavy minerals analyses were done with a polarising microscope after separation using Bromoform. Both analyses were done in the Thin Section Laboratory of the Earth Sciences Department in the University of Yaoundé 1. Mineralogical data were obtained by X-ray diffraction using a 2080 sigma diffractometer 
coupled with a $\mathrm{Cu}$ anticathode on bulk sample powders and fine clayey $(0-2 \mu \mathrm{m})$ fractions; The presence of smectite was confirmed by means of ethylene glycol test [44]. The chemical analyses were performed on disoriented samples using Inductively Coupled Plasma-Atomic Emission Spectrometry (ICP-AES) after fusion in $\mathrm{LiBO}_{2}$ and dissolution in Nitric acid. Both X-ray diffraction and ICP-AES analyses were performed in the C.R.P.G (Centre de Recherche Pétrographique et Géologique) of Nancy (France), meanwhile additional analyses for pit $\mathrm{P}_{2}$ were done at the Local Materials Promotion Authority in Yaoundé (Cameroon). The physical and physico-chemical analyses were done in the "Laboratoire de Physico-chimie des Matériaux Minéraux" (University of Yaoundé 1) and at the IITA (International Institute for Tropical Agriculture) Nkolbissong, Yaoundé. So, bulk density $\left(D_{b}\right)$ was determined in reference to Archimedes' principle, real density $\left(D_{r}\right)$ was measured by pycnometer method [1]. Porosity $(\mathrm{P})$ was calculated from real and bulk densities as:

$\mathrm{P}=($ Dr-Db/Dr) x 100 .

The morphoscopic analyses were done by the random selection of 50 sand-sized quartz grains and the observation of their surface aspects with a binocular lens. Calculation of residual humidity data was done on the basis of oven-dry $\left(105^{\circ} \mathrm{C}\right)$ soil mass and the particle size distribution was measured by Robinson's pipette method [1]. The $\mathrm{pH}-\mathrm{H}_{2} \mathrm{O}$ was determined in a soil/water ratio of $1: 2 \frac{1}{2}$ and $\mathrm{pH}-\mathrm{KCl}$ in a soil/ $/ \mathrm{KCl}$ ratio of $1: 2 \frac{1}{2}$ using a glass $\mathrm{pH}$ meter [45]. The presence of carbonates was tested with dilute $\mathrm{HCl}$ solution. The organic carbon (OC) was measured by Walkley-Black procedure [46]. The organic matter was deduced from the Springel's coefficient [1]. Total nitrogen (TN) was measured by the Kjeldahl method [47]. Available phosphorus was determined by concentrated nitric acid reduction method [48]. Exchangeable cations were dosed by ammonium acetate extraction method [49] and cation exchange capacity (CEC) was determined using the sodium saturation method [50]. The free iron was measured by selective extractions with citrate bicarbonate dithionate (CBD) [51].

The mechanical analyses were performed in the "Laboratoire de Physico-chimie de Matériaux Minéraux" (University of Yaoundé 1), MIPROMALO (Local Materials Promotion Authority) and LABOGENIE (National Civil Engineering Laboratory) in Yaoundé (Cameroon). Thus, free swelling rate was measured by saturating fine soil samples (diameter $\leq 2 \mathrm{~mm}$ ) with water and noting the change in volume after centrifugation during 10 minutes and comparing with a standard sample [52]. The potential swelling rate was measured by dispersing vertisol samples in $2 \% \mathrm{Na}_{2} \mathrm{CO}_{3}$, instead of water, so as to render them sodic before centrifugation. The plastic limits (WL) and liquid limits (WL) were obtained as described in the American Standard for Testing Materials [53]. The plasticity indices (WI) were deduced as the difference between the plastic limit and liquid limit. Shrinkage limit was determined from liquid and plastic limits standard tables. The activity of the material was the ratio of the plasticity index (WI) to the total clay content (\% clay). The group index (Ig) of the horizons was deduced from standard tables and from the following formula [52]:

$\operatorname{Ig}=0.2 \mathrm{a}+0.005 \mathrm{ac}+0.01 \mathrm{bd}$ where, Ig is the group index; a, b, c and d are constants that depend on the plasticity limit, the plasticity index and on the proportion of the vertisols that passed through an $80 \mu \mathrm{m}$ sieve. The compression $(\mathrm{Cc})$ limit was estimated from the liquid limit according to Costet and Sanglerat [54]:

$$
\mathrm{Cc}=0.0064(\mathrm{Wl}-10)
$$

\section{RESULTS}

\subsection{Microscopic Analysis}

The microscopic analysis of vertisol samples revealed that the $\mathrm{B}_{3 \mathrm{~g}}$ horizons had a yellowish brown groundmass, constituted by yellowish brown plasma, skeletal grains, and voids (Fig. 5a). Plasma (75\% of the groundmass) was very dense, averagely birefringent and clearly oriented, with stress cutans that followed two principal directions and thus conferred to the material, a bimasepic and a locally lattisepic structure. Skeleton represented about $15 \%$ of the whole groundmass; it encompassed quartz grains $(80 \%$ of total skeleton) and opaque minerals. Quartz grains were heterometric, with dimensions ranging between 100 and 300 $\mu \mathrm{m}$; angular grains were the most abundant, mixed with sub-angular and sub-rounded ones, and some of them showed cracks. Opaque minerals were dense and their dimensions varied between 150 and $250 \mu \mathrm{m}$. The skeletal grains were completely wrapped in the plasma, and defined with it, a porphyroskelic distribution pattern. Voids made up $10 \%$ of the whole groundmass; they were mainly constituted by very fine and regularly distributed fissures and few tiny alveolar voids of about $200 \mu \mathrm{m}$ diameter (Fig. 5a). The $\mathrm{B}_{21}$ and the $\mathrm{B}_{1}$ horizons were microscopically similar to one another and to the previous horizons (Fig. $\mathbf{5 b}, \mathbf{c}$ ). The grey horizons $\left(A_{1}\right)$ of the various profiles differed from the underlying ones by the presence of isotic plasmas (Fig. 5d).

The observations of heavy mineral thin sections of vertisol samples from the three sites enabled to underline three main classes of heavy minerals including metamorphic minerals (andalusite, sillimanite, kyanite, diopside, zoisite, garnet and epidote), magmatic minerals (augite, aegerine and aegerinic augite) and mixed minerals (green hornblende, rutile, zircon, hypersthene, biotite, and muscovite, opaque oxides) (Table 1).

Overall, under the microscope, the studied soils showed abundant plasmas which were isotic at the surface but very birefringent at depth marked by the presence of numerous stress cutans. Heavy mineral analysis revealed the presence of metamorphic, volcanic and plutonic minerals as well as mixed minerals.

\subsection{Mineralogical and Geochemical Analyses}

\subsubsection{Mineralogical Composition}

The mineralogical analysis revealed that smectite was the most abundant mineral constituent in all the soil profiles (Table 2). It was associated with kaolinite and to small proportions with illite, quartz and feldspars, and with traces of goethite and ilmenite (Fig. 6A, B). The results of the ethylene glycol test on one sample showed a characteristic displacement of the principal peak of smectite from $15.40 \AA$ to $17.75 \AA$ (Fig. 7). All the vertisol profiles showed a similar mineralogical composition. 


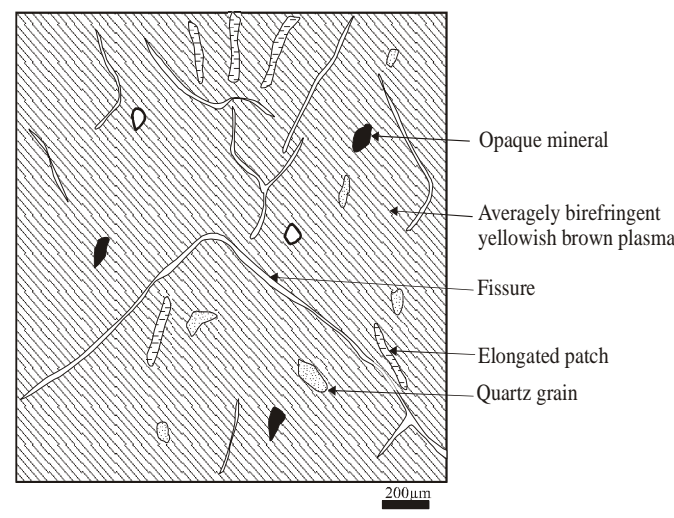

(a) (b) $\mathrm{B}_{3 \mathrm{~g}}(150-250 \mathrm{~cm})$ horizon

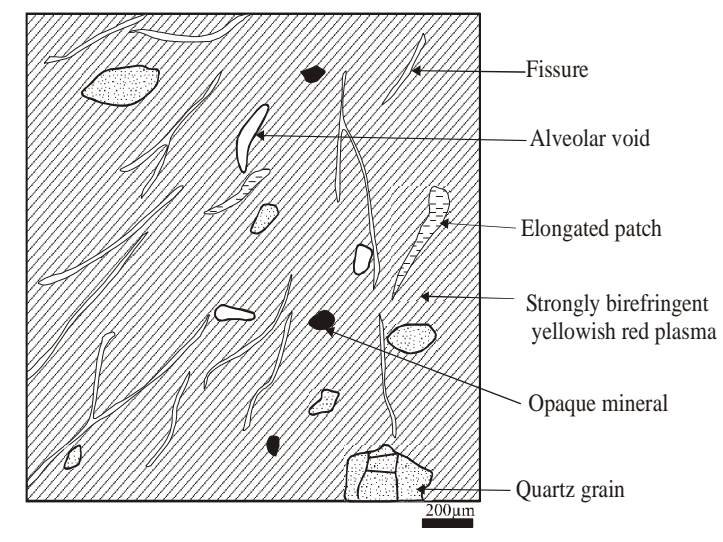

(c) $\mathrm{B}_{1}(30-100 \mathrm{~cm})$ horizon

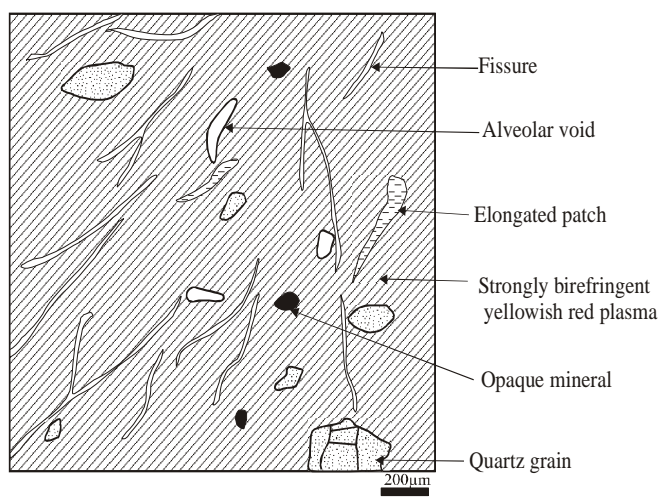

(b) $\mathrm{B}_{21}(100-150 \mathrm{~cm})$ horizon

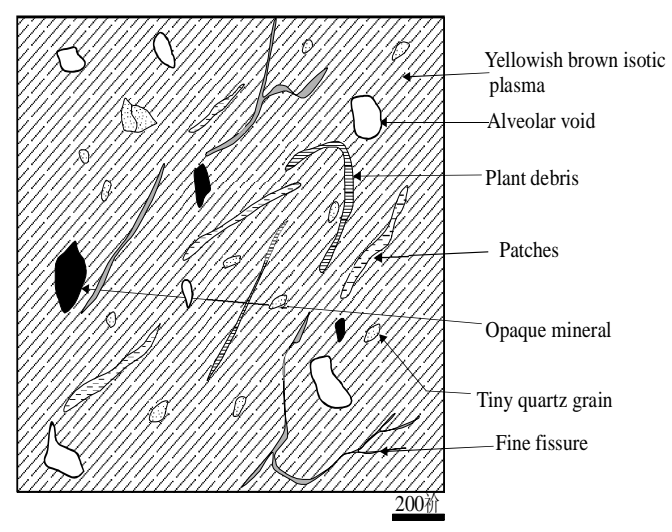

(d) $\mathrm{A}_{1}(0-30 \mathrm{~cm})$

Fig. (5). Microscopic organisation of the different vertisol horizons.

Therefore, in all three sites, smectite was the most abundant mineral, associated with kaolinite and with small proportions of quartz, feldspar and illite, as well as traces of goethite and ilmenite (Table 2).

\subsubsection{Geochemistry}

Geochemical analyses revealed that the studied profiles were mainly constituted by silicon $\left(50.35-54.01 \% \mathrm{SiO}_{2}\right)$, aluminium $\left(18.36-21.66 \% \mathrm{Al}_{2} \mathrm{O}_{3}\right)$ and iron $(5.35-7.91 \%$ $\mathrm{Fe}_{2} \mathrm{O}_{3}$ ) (Fig. 8; Table 3). Titanium (1.01-1.51\% $\mathrm{TiO}_{2}$ ), alkaline $\left(0.53-1.47 \% \quad \mathrm{Na}_{2} \mathrm{O}\right.$ and $\left.1.77-3.22 \% \quad \mathrm{~K}_{2} \mathrm{O}\right)$ and alkali-earth elements (1.00-1.68\% $\mathrm{CaO}$ and $1.06-2.8 \% \mathrm{MgO})$ were also present, and $\mathrm{K}$ was the most represented base in all the profiles (Table 2). Specifically for profile $\mathrm{P}_{1}$, towards the top of the soils, the chemical composition of the different horizons globally remained unchanged, particularly for the three main elements $\mathrm{Si}, \mathrm{Al}$ and $\mathrm{Fe}$ whose vertical evolution was quite regular (Table 3), just showing a very slight decrease of $\mathrm{Al}$ and $\mathrm{Fe}$ contents (Table 3). $\mathrm{Na}, \mathrm{Mg}$ and $\mathrm{K}$ whose contents varied between 0.53 to $0.92 \% \mathrm{Na}_{2} \mathrm{O}, 1.20$ to $1.38 \% \mathrm{MgO}$ and 1.77 to $2.18 \% \mathrm{~K}_{2} \mathrm{O}$, showed the same vertical evolution trends; they showed a slight increase at the middle part of the profile, then a slight decrease towards the top. Ti, $\mathrm{Mn}$ and $\mathrm{P}$ evolution curves were quite constant all along the profile, except at the $\mathrm{A}_{1}(0-30)$ horizon where $\mathrm{P}$ contents varied quite notably decreasing from 0.16 to $0.09 \%$ $\mathrm{P}_{2} \mathrm{O}_{5}$ (Table 3). The chemical compositions of profile $\mathrm{P}_{2}$ and $\mathrm{P}_{3}$ were identical to that of profile $\mathrm{P}_{1}$. More so, the behaviour of all chemical elements was quite regular with only mild fluctuations with depth. In the $\mathrm{SiO}_{2}-\mathrm{Al}_{2} \mathrm{O}_{3}-\mathrm{Fe}_{2} \mathrm{O}_{3}$ triangular diagram, the samples of all the horizons were located in the same area, near the $\mathrm{SiO}_{2}$ pole (Fig. 9). This confirmed the predominance of silicon in those soils and the uniformity of their chemical composition. Moreover, Si/Al ratio varied between 2.27 and 2.94, Si remaining clearly more abundant than $\mathrm{Al}$ the second most important element of those soils. 


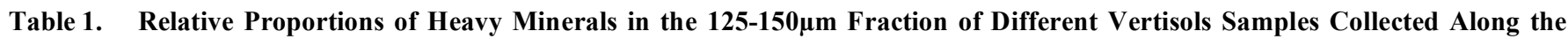
Benue River Floodplain

\begin{tabular}{|c|c|c|c|c|c|c|c|c|}
\hline Heavy Mineral & Gar1 & Gar2 & Gar3 & Gar4 & Poum1 & Poum2 & Boun1 & Boun2 \\
\hline Kyanite & - & - & - & - & 1 & - & - & - \\
\hline Tourmaline & 6 & 2 & & & & & 3 & 3 \\
\hline Andalousite & - & - & - & 4 & 3 & 4 & & \\
\hline Sillimanite & - & - & - & 4 & - & - & - & 3 \\
\hline Muscovite & & 4 & & & 3 & & & \\
\hline Biotite & - & - & 5 & 11 & - & - & 3 & 5 \\
\hline Rutile & 2 & 2 & 1 & - & 1 & & 3 & \\
\hline Zircon & 20 & 15 & 5 & 3 & - & - & - & - \\
\hline Green $\mathrm{Hb}$ & & 2 & 1 & 1 & & 1 & 3 & \\
\hline Green epidote & 16 & 2 & 16 & 13 & 18 & 14 & 28 & 28 \\
\hline Aegerine & 2 & 2 & - & - & - & - & 3 & - \\
\hline Augite & 2 & 7 & 5 & - & 8 & - & 7 & 5 \\
\hline Aegerinic augite & - & - & 2 & - & 1 & - & - & - \\
\hline Hypersthene & - & - & - & - & 3 & - & - & - \\
\hline Diopsite & - & & 2 & - & 1 & - & - & - \\
\hline Zoisite & - & 7 & - & 1 & 8 & 4 & 3 & - \\
\hline Topaz & - & - & - & 1 & - & - & - & - \\
\hline Apatite & - & - & - & 2 & - & - & - & - \\
\hline Garnet & 4 & 5 & 10 & 6 & - & - & 7 & 8 \\
\hline Opaque & 43 & 46 & 43 & 49 & 46 & 69 & 30 & 45 \\
\hline Undetermined & 5 & 6 & 9 & 7 & 4 & 9 & 3 & 4 \\
\hline
\end{tabular}

Gar $=$ Garoua; Poum $=$ Poumpoumré; Boun $=$ Bounguel.

Table 2. Mineralogical Composition of the Vertisol Whole Sample Powders (Semi-Quantitative Estimation Based on the Main Peak Intensity of Each Mineral)

\begin{tabular}{|c|c|c|c|c|c|c|c|}
\hline Horizon & Sm & $\mathbf{K}$ & Qz & $\mathbf{F p}$ & Il & Ilm & Go \\
\hline $\mathrm{B}_{1}(30-100 \mathrm{~cm})$ horizon & ++++ & +++ & ++ & ++ & ++ & + & + \\
\hline $\mathrm{B}_{21}(100-150 \mathrm{~cm})$ horizon & ++++ & +++ & ++ & ++ & ++ & + & + \\
\hline
\end{tabular}

\subsection{Physico-Chemical Characteristics}

\subsubsection{Physical Properties}

The real density equals 2.6 in all bottom horizons, and 2.5 at the surface, where a slight decrease was observed for all the studied soils (Table 4). The bulk density regularly and slightly decreased from bottom to top, varying from 1.8 to 2.2 , of the profile (Table 4). The total porosity regularly ranged from 15.40 to $28.00 \%$. It decreased with depth in all the studied sites (Table 4). The residual humidity was quite comparable for all the sites and showed a slight increase with depth (Table 4). The grain size distribution analysis revealed that the clayey fraction $(0-2 \mu \mathrm{m})$ was the most abundant in all the soils. Clay proportions gradually decreased from the base to the surface of all studied profiles. The clay contents were highest and quite comparable in Garoua Brasseries and Poumpoumré and ranged between 62.5 and 75\% (Table 4). In all the studied profiles, the highest silt contents appeared at the surface of all horizons, and then gradually decreased 


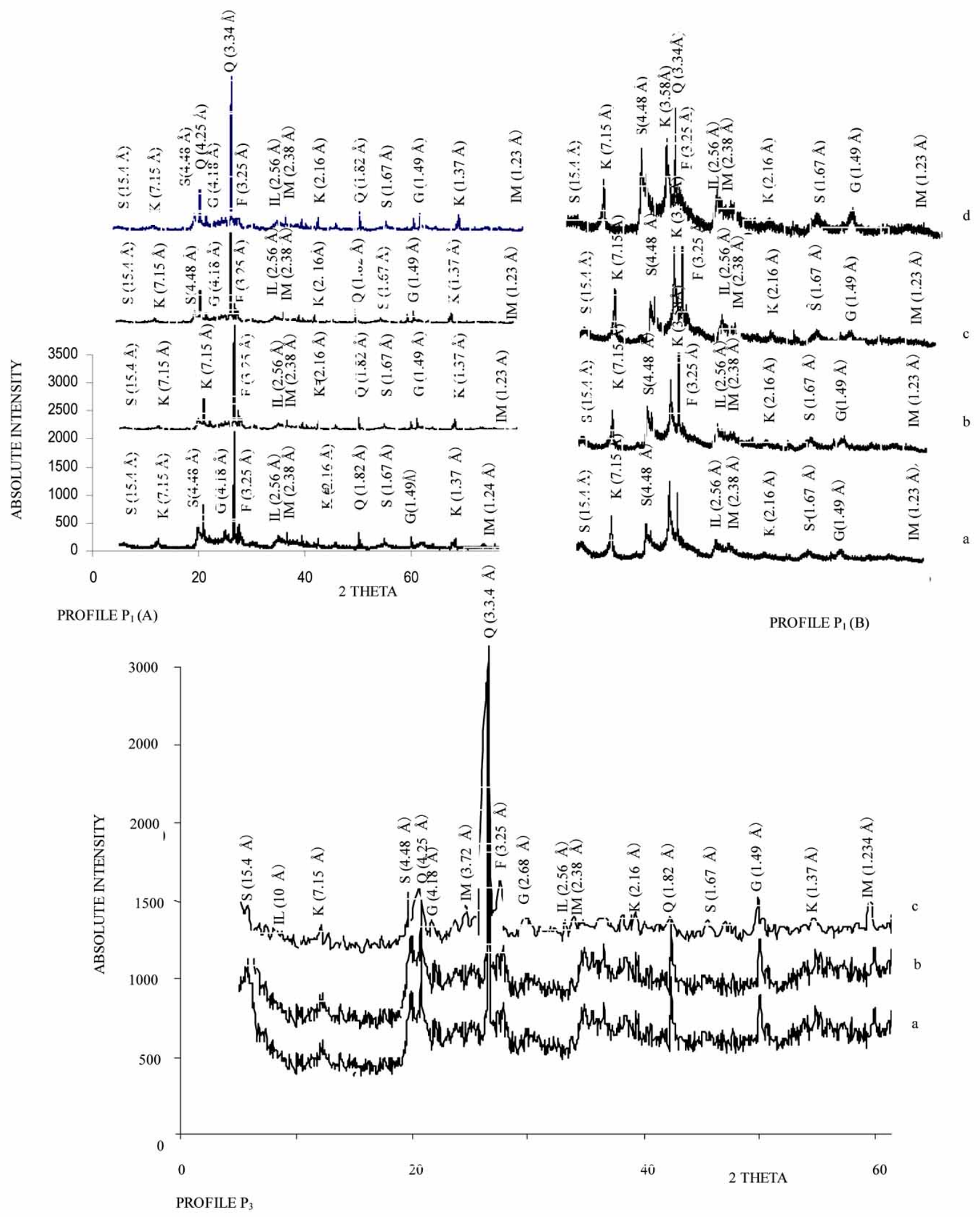

Fig. (6). X-ray diffraction patterns of the whole samples $(\mathbf{A})$ and the fine clayey fraction samples $(\mathbf{B})$ from the different vertisol horizons $(\mathrm{a}=$ $\mathrm{B}_{3} \mathrm{~g}$ horizon; $\mathrm{b}=\mathrm{B}_{21}$ horizon; $\mathrm{c}=\mathrm{B}_{1}$ horizon; $\mathrm{d}=\mathrm{A}_{1}$ horizon.

with depth. Sand presented a contrary trend to those of clay and silt. The highest sand contents were observed in Bounguel (Table 4). The fine sand to coarse sand ratio (FS/CS) generally increased from the base to the surface of all the profiles. The representation of various grain size fractions on Jamagne's textural diagram [55] showed that the soils from Garoua and Poumpoumré had a heavy clayey texture, while those from Bounguel displayed a clayey texture (Fig. 10). The morphoscopic observations of quartz grains revealed the preponderance of angular grains as well as small proportions of sub-angular and blunt shiny rounded grains (Table 5). 
Table 3. Chemical Composition of the Vertisols from the Benue Floodplain (Expressed in Percentage Oxide)

Profile $P_{1}$

\begin{tabular}{|c|c|c|c|c|c|c|c|c|c|c|c|c|c|}
\hline (Depth) & $\mathrm{SiO}_{2}$ & $\mathbf{A l}_{2} \mathbf{O}_{3}$ & $\mathrm{Fe}_{2} \mathrm{O}_{3}$ & MnO & MgO & $\mathrm{CaO}$ & $\mathrm{Na}_{2} \mathrm{O}$ & $\mathrm{K}_{2} \mathrm{O}$ & $\mathrm{TiO}_{2}$ & $\mathbf{P}_{2} \mathbf{O}_{3}$ & LOI & Total & $\mathbf{S i} / \mathbf{A l}$ \\
\hline$A_{1}(0-30 \mathrm{~cm})$ & 53.46 & 18.88 & 6.72 & 0.08 & 1.06 & 1.16 & 0.87 & 1.85 & 1.02 & 0.09 & 14.64 & 99.89 & 2.50 \\
\hline $\mathrm{B}_{1}(30-100 \mathrm{~cm})$ & 53.29 & 18.79 & 6.60 & 0.06 & 1.34 & 1.00 & 0.88 & 2.18 & 1.01 & 0.16 & 14.61 & 99.89 & 2.40 \\
\hline $\mathrm{B}_{21}(100-150 \mathrm{~cm})$ & 53.40 & 19.07 & 6.89 & 0.09 & 1.38 & 1.38 & 0.92 & 2.11 & 1.11 & 0.19 & 14.03 & 100.17 & 2.40 \\
\hline $\mathrm{B}_{3 \mathrm{~g}}(150-250 \mathrm{~cm})$ & 53.15 & 20.66 & 7.20 & 0.06 & 1.20 & 1.20 & 0.53 & 1.77 & 1.08 & 0.21 & 13.07 & 99.88 & 2.27 \\
\hline
\end{tabular}

Profile $\mathbf{P}_{2}$

\begin{tabular}{|c|c|c|c|c|c|c|c|c|c|c|c|c|c|}
\hline $\begin{array}{l}\text { Oxide (\%) } \\
\text { (Depth) }\end{array}$ & $\mathrm{SiO}_{2}$ & $\mathbf{A l}_{2} \mathbf{O}_{3}$ & $\mathrm{Fe}_{2} \mathrm{O}_{3}$ & MnO & MgO & $\mathrm{CaO}$ & $\mathrm{Na}_{2} \mathrm{O}$ & $\mathbf{K}_{2} \mathbf{O}$ & $\mathrm{TiO}_{2}$ & $\mathbf{P}_{2} \mathbf{O}_{3}$ & LOI & Total & $\mathbf{S i} / \mathbf{A l}$ \\
\hline$A_{1}(0-40 \mathrm{~cm})$ & 50.35 & 21.49 & 7.91 & 0.06 & 1.79 & 1.34 & 1.35 & 2.96 & 2.46 & 0.04 & 10.30 & 100.05 & 2.34 \\
\hline $\mathrm{B}_{1}(40-110 \mathrm{~m})$ & 50.81 & 21.35 & 7.69 & 0.11 & 2.44 & 1.35 & 1.47 & 2.51 & 1.51 & 0.15 & 11.10 & 100.49 & 2.38 \\
\hline $\mathrm{B}_{21}(110-210 \mathrm{~cm})$ & 51.31 & 21.61 & 7.44 & 0.11 & 2.11 & 1.28 & 1.43 & 2.45 & 1.46 & 0.17 & 11.45 & 100.82 & 2.32 \\
\hline
\end{tabular}

Profile $\mathbf{P}_{3}$

\begin{tabular}{|c|c|c|c|c|c|c|c|c|c|c|c|c|c|}
\hline$A_{1}(0-60 \mathrm{~cm})$ & 55.51 & 18.36 & 6.51 & 0.06 & 2.8 & 1.46 & 1.10 & 2.73 & 1.10 & 0.03 & 12.53 & 100.19 & 2.94 \\
\hline $\mathrm{B}_{1}(60-150 \mathrm{~m})$ & 52.05 & 19.29 & 5.53 & 0.05 & 2.6 & 1.60 & 1.41 & 3.22 & 1.18 & $<0.001$ & 12.05 & 99.98 & 2.70 \\
\hline
\end{tabular}

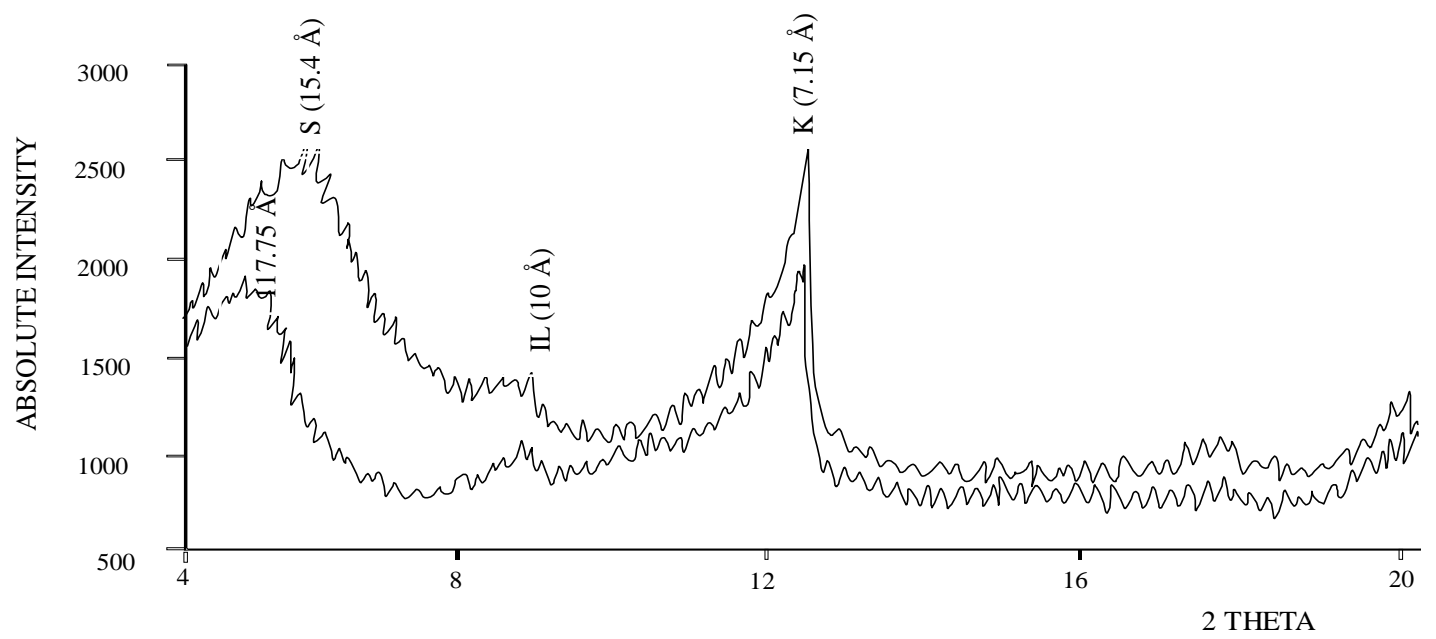

Fig. (7). X-ray diffractogram of the $A_{1}$ horizon $(0-30 \mathrm{~cm})$ after treatment with ethylene glycol $(\mathrm{S}=$ smectite; $K=\mathrm{Kaolinite} ; \mathrm{IL}=\mathrm{Illite})$. 


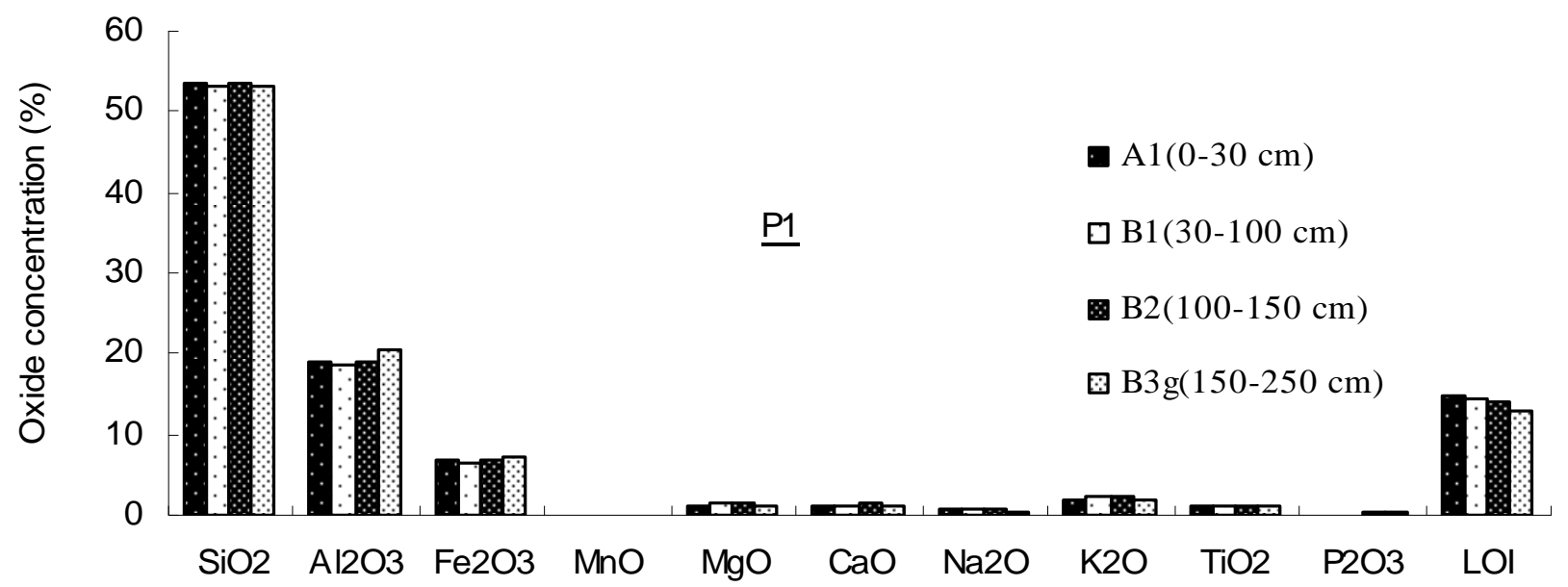

Oxides
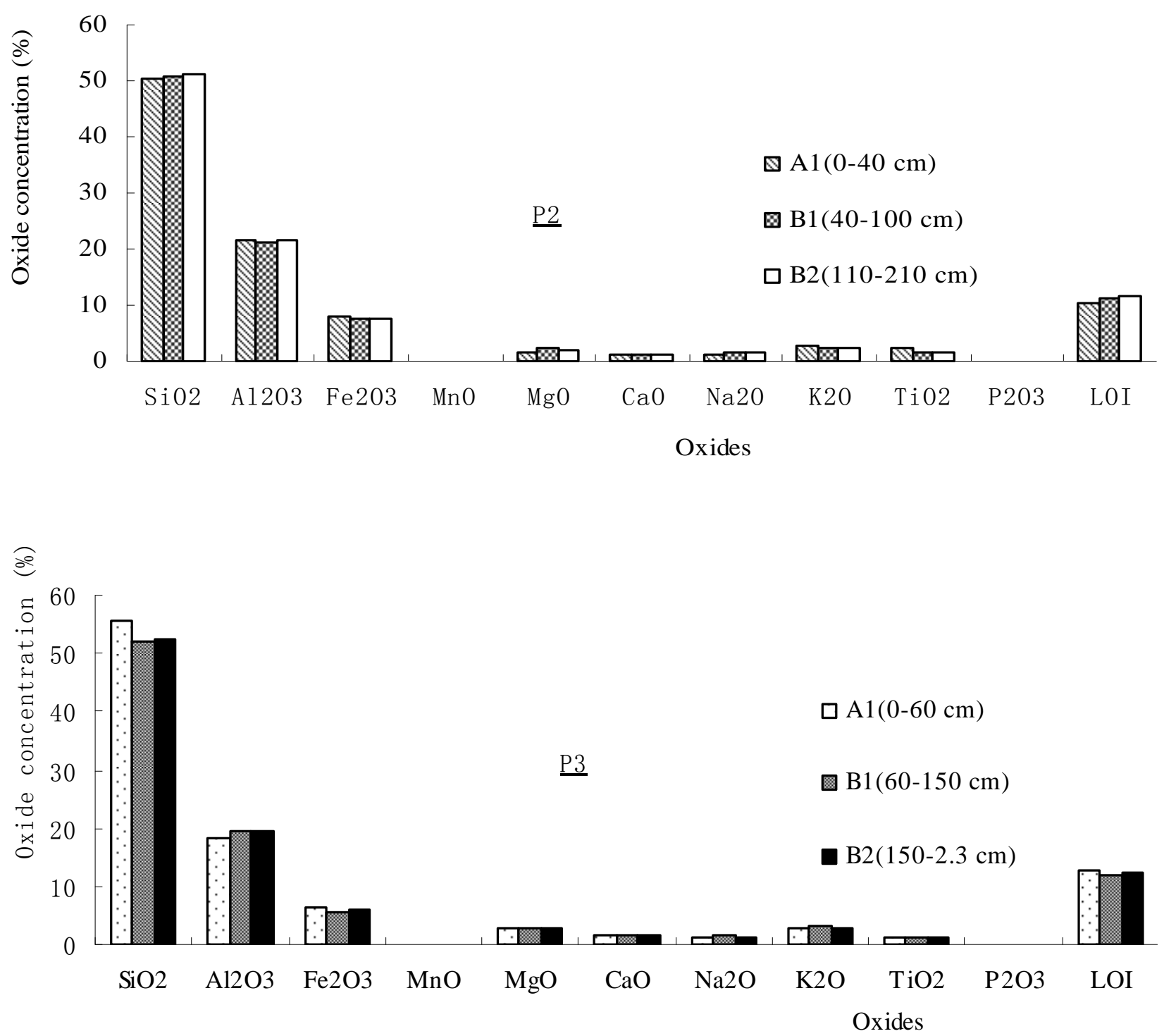

Fig. (8). Comparative chemical compositions of the different vertisol profiles $\left(\mathrm{P}_{1}, \mathrm{P}_{2}\right.$ and $\left.\mathrm{P}_{3}\right)$. 
Table 4. Physical Characteristics of the Topomorphic Vertisols from the Benue Floodplain of North Cameroon

Profile $\mathbf{P}_{1}$

\begin{tabular}{|c|c|c|c|c|c|c|c|c|c|c|}
\hline Physical & & & & & \multicolumn{6}{|c|}{ Particle Size Distribution (\%) } \\
\hline $\begin{array}{l}\text { Horizon } \\
\text { (Depth) }\end{array}$ & $\begin{array}{c}\text { Real } \\
\text { Density }\end{array}$ & $\begin{array}{c}\text { Bulk } \\
\text { Density }\end{array}$ & $\begin{array}{c}\text { Porosity } \\
\text { (\%) }\end{array}$ & $\begin{array}{c}\text { Residual } \\
\text { Humidity (\%) }\end{array}$ & $\begin{array}{l}\text { Coarse } \\
\text { Sand }\end{array}$ & $\begin{array}{l}\text { Fine } \\
\text { Sand }\end{array}$ & $\begin{array}{l}\text { Coarse } \\
\text { Silt }\end{array}$ & $\begin{array}{c}\text { Fine } \\
\text { Silt }\end{array}$ & Clay & Total \\
\hline $\mathrm{A}_{1}(0-30 \mathrm{~cm})$ & 2.5 & 1.8 & 28.0 & 6.70 & 4.30 & 6.54 & 11.66 & 15.00 & 62.50 & 100.00 \\
\hline $\mathrm{B}_{1}(30-100 \mathrm{~cm})$ & 2.6 & 2.1 & 19.0 & 8.10 & 2.15 & 4.15 & 12.50 & 12.50 & 70.00 & 101.30 \\
\hline $\mathrm{B}_{21}(100-150 \mathrm{~cm})$ & 2.6 & 2.1 & 19.0 & 9.70 & 4.05 & 2.45 & 8.50 & 8.50 & 72.50 & 100.00 \\
\hline $\mathrm{B}_{3 \mathrm{~g}}(150-250 \mathrm{~cm})$ & 2.6 & 2.2 & 15.4 & 10.30 & 2.70 & 4.80 & 12.50 & 06.36 & 75.00 & 101.10 \\
\hline
\end{tabular}

Profile $\mathbf{P}_{2}$

\begin{tabular}{|c|c|c|c|c|c|c|c|c|c|c|}
\hline \multirow{2}{*}{$\begin{array}{l}\text { Horizon } \\
\text { (Depth) }\end{array}$} & \multirow[b]{2}{*}{$\begin{array}{c}\text { Real } \\
\text { Density }\end{array}$} & \multirow[b]{2}{*}{$\begin{array}{l}\text { Bulk } \\
\text { Density }\end{array}$} & \multirow[b]{2}{*}{$\begin{array}{c}\text { Porosity } \\
\text { (\%) }\end{array}$} & \multirow[b]{2}{*}{$\begin{array}{c}\text { Residual } \\
\text { Humidity (\%) }\end{array}$} & \multicolumn{6}{|c|}{ Particle Size Distribution (\%) } \\
\hline & & & & & $\begin{array}{l}\text { Coarse } \\
\text { Sand }\end{array}$ & $\begin{array}{l}\text { Fine } \\
\text { Sand }\end{array}$ & $\begin{array}{l}\text { Coarse } \\
\text { Silt }\end{array}$ & $\begin{array}{c}\text { Fine } \\
\text { Silt }\end{array}$ & Clay & Total \\
\hline $\mathrm{A}_{1}(0-40 \mathrm{~cm})$ & 2.5 & 1.9 & 24.0 & 7.90 & 7.15 & 3.55 & 8.00 & 14.50 & 68 & 101.20 \\
\hline $\mathrm{B}_{1}(40-110 \mathrm{~cm})$ & 2.6 & 2.1 & 19.0 & 8.8 & 3.36 & 8.59 & 6.28 & 9.75 & 72 & 99.98 \\
\hline $\mathrm{B}_{21}(110-210 \mathrm{~cm})$ & 2.6 & 2.1 & 19.0 & 9.3 & 3.84 & 2.56 & 8.22 & 11.78 & 75 & 101.40 \\
\hline
\end{tabular}

Profile $\mathbf{P}_{3}$

\begin{tabular}{|c|c|c|c|c|c|c|c|c|c|c|}
\hline \multirow{2}{*}{$\begin{array}{l}\text { Horizon } \\
\text { (Depth) }\end{array}$} & \multirow[b]{2}{*}{$\begin{array}{c}\text { Real } \\
\text { Density }\end{array}$} & \multirow[b]{2}{*}{$\begin{array}{c}\text { Bulk } \\
\text { Density }\end{array}$} & \multirow[b]{2}{*}{$\begin{array}{c}\text { Porosity } \\
\text { (\%) }\end{array}$} & \multirow[b]{2}{*}{$\begin{array}{c}\text { Residual } \\
\text { Humidity (\%) }\end{array}$} & \multicolumn{6}{|c|}{ Particle Size Distribution (\%) } \\
\hline & & & & & $\begin{array}{c}\text { Coarse } \\
\text { Sand }\end{array}$ & $\begin{array}{l}\text { Fine } \\
\text { Sand }\end{array}$ & $\begin{array}{l}\text { Coarse } \\
\text { Silt }\end{array}$ & $\begin{array}{l}\text { Fine } \\
\text { Silt }\end{array}$ & Clay & Total \\
\hline $\mathrm{A}_{1}(0-60 \mathrm{~cm})$ & 2.5 & 1.8 & 28.0 & 7.70 & 08.28 & 16.68 & 13.40 & 18.28 & 45.00 & $\overline{101.24}$ \\
\hline $\mathrm{B}_{1}(60-150 \mathrm{~cm})$ & 2.6 & 2.0 & 23.10 & 7.9 & 07.10 & 22.36 & 09.08 & 14.88 & 47.50 & 100.92 \\
\hline $\mathrm{B}_{21}(150-2.3 \mathrm{~cm})$ & 2.6 & 2.2 & 15.40 & 10.80 & 7.79 & 15.10 & 13.08 & 13.30 & 53.50 & 99.98 \\
\hline
\end{tabular}

\subsubsection{Physico-Chemical Characteristics}

The $\mathrm{pH}-\mathrm{H}_{2} \mathrm{O}$ ranged between 5.6 and 7.2 (Table 6) and revealed acidic to slightly basic soils. Excluding Garoua Brasseries, $\mathrm{pH}-\mathrm{H}_{2} \mathrm{O}$ was slightly lower at the surface than at the bottom part of all the profiles (Table 6). The $\mathrm{pH}-\mathrm{KCl}$, less than $\mathrm{pH}-\mathrm{H}_{2} \mathrm{O}$ was more acidic; it regularly and slightly increased with depth for all the regions apart from Garoua where an opposite trend was observed. The exchangeable acidity $(\Delta \mathrm{pH})$ was generally close to or greater than 1 (Table 6). The organic carbon was low for all the soils and more represented in the surface horizons than in the sub-surface ones where a sharp decrease was observed. The highest values were observed in Garoua (4.5\%) and the lowest ones in Bounguel (Table 6). The bottom horizons were the poorest in carbon. The total nitrogen contents varied between $0.1 \%$ and $0.02 \%$. The $\mathrm{C} / \mathrm{N}$ ratio fluctuated between 10.20 and 26.20 (Table 6). The highest values were observed in Garoua Brasseries while the lowest ones appeared in Bounguel. Available phosphorus contents varied between 13.12 and 75.53 ppm (Table 6) in all three sites (Table 6). Also, this element decreases with depth in all the profiles, with the $A_{1}$ horizon being the richest in phosphorus. The sum of exchangeable bases for all the studied soils ranged between 24.36 and $37.14 \mathrm{meq} / 100 \mathrm{~g}$ of soil (Table 6). It increased regularly with profile depth. Calcium was the dominant exchangeable cation, with contents ranging between 15.20 and $26.60 \mathrm{meq} / 100 \mathrm{~g}$ of soil, which was about 60 to $70 \%$ of total bases. It was followed by magnesium (6.9 to 11.60 $\mathrm{meq} / 100 \mathrm{~g}$ of soil), while sodium and potassium showed more modest values $(0.52$ to $1.78 \mathrm{meq} / 100 \mathrm{~g}$ of soil for sodium, and 0.40 to $1.99 \mathrm{meq} / 100 \mathrm{~g}$ of soil for potassium) (Table 6). It was realised that calcium and magnesium contents increased with depth, while those of sodium and potassium showed an opposite trend (Table 6). The cation exchange capacity (me/100g) varied between 26 and 42 $\mathrm{meq} / 100 \mathrm{~g}$, and globally increased from the surface to the base of all the profile. Base saturation $(\mathrm{S} / \mathrm{T})$ globally fluctuated from 74.30 to 94.23 (Table 6). It increased with depth of all profiles except in Bounguel where a slight decrease was observed in the middle horizon. $\mathrm{Na} / \mathrm{T}$ ratio ranged between 1.17 and 5.09 in all the studied sites. The free iron $\left(\mathrm{Fe}_{\mathrm{CBD}}\right)$ content fluctuated between 2.62 and $3.94 \%$ 
Table 5. Morphoscopic Analysis of the Vertisol Samples from the Benue Floodplain

\begin{tabular}{|c|c|c|c|c|c|}
\hline \multirow{2}{*}{ Sample } & \multirow{2}{*}{ Particle Size (in Microns) } & \multicolumn{4}{|c|}{ Shape/Surface Aspect } \\
\hline & & Angular & Sub-Angular & Rounded (Blunt Shiny) & Dull Rounded \\
\hline \multirow{4}{*}{ Gar1 } & $>1000$ & 70 & 20 & 10 & 0 \\
\hline & $1000-500$ & 60 & 18 & 16 & 6 \\
\hline & $500-315$ & 70 & 18 & 16 & 2 \\
\hline & $315-123$ & 66 & 12 & 16 & 6 \\
\hline \multirow{4}{*}{ Gar2 } & $>1000$ & - & - & - & - \\
\hline & $1000-500$ & 84 & 8 & 6 & 2 \\
\hline & $500-315$ & 70 & 16 & 14 & 0 \\
\hline & $315-123$ & 58 & 12 & 22 & 8 \\
\hline \multirow{4}{*}{ Gar3 } & $>1000$ & 64 & 28 & 8 & 0 \\
\hline & $1000-500$ & 68 & 8 & 18 & 6 \\
\hline & $500-315$ & 56 & 16 & 20 & 4 \\
\hline & $315-123$ & 48 & 10 & 40 & 6 \\
\hline \multirow{4}{*}{ Gar4 } & $>1000$ & 62 & 28 & 12 & 0 \\
\hline & $1000-500$ & 48 & 10 & 40 & 6 \\
\hline & $500-315$ & 54 & 12 & 34 & 0 \\
\hline & $315-123$ & 46 & 20 & 30 & 40 \\
\hline \multirow{4}{*}{ Poum1 } & $>1000$ & 70 & 18 & 10 & 2 \\
\hline & $1000-500$ & 80 & 12 & 8 & 0 \\
\hline & $500-315$ & 76 & 10 & 14 & 0 \\
\hline & $315-123$ & 72 & 14 & 14 & 0 \\
\hline \multirow{4}{*}{ Poum2 } & $>1000$ & 74 & 18 & 8 & 0 \\
\hline & $1000-500$ & 70 & 20 & 10 & 0 \\
\hline & $500-315$ & 76 & 10 & 12 & 4 \\
\hline & $315-123$ & 62 & 16 & 20 & 2 \\
\hline \multirow{4}{*}{ Boun1 } & $>1000$ & 82 & 10 & 08 & 0 \\
\hline & $1000-500$ & 76 & 16 & 12 & 0 \\
\hline & $500-315$ & 70 & 18 & 12 & 0 \\
\hline & $315-123$ & 60 & 22 & 18 & 0 \\
\hline \multirow{4}{*}{ Boun2 } & $>1000$ & 70 & 18 & 10 & 2 \\
\hline & $1000-500$ & 64 & 28 & 8 & 0 \\
\hline & $500-315$ & 82 & 10 & 6 & 2 \\
\hline & $315-123$ & 58 & 28 & 14 & 0 \\
\hline
\end{tabular}

Gar = Garoua $;$ Poum $=$ Poumpoumré Boun $=$ Bounguel.

(Table 6). It was slightly stable with depth, showing only a light increase in all the profiles. The highest free iron contents occurred at Poumpoumré (3.73 to 3.94\%) and these values were very close to those in Garoua but slightly more pronounced compared to those of Bounguel (2.85 to 3.47\%). The $\mathrm{Fe}_{\mathrm{CBD}} / \mathrm{Fe}_{\mathrm{T}}$ globally varied between 43 and $57 \%$. The ratios are quite comparable in all the studied soils and all increased with depth (Table 6).

\subsection{Mechanical Properties}

The free swelling rate (in water) ranged between 10 and $25 \%$ in the studied soils and increased with depth of profiles (Table 7). Potential swelling (in $2 \% \mathrm{Na}_{2} \mathrm{CO}_{3}$ ) also increased with depth from 60 to $85 \%$; these values were four to six folds higher than those recorded for the free swelling rates (Table 7). The liquid limits ranged between 36 and $46 \%$ (Table 7); those values increased with profile depth in all the soils apart from the Garoua profile where they evolved in a 


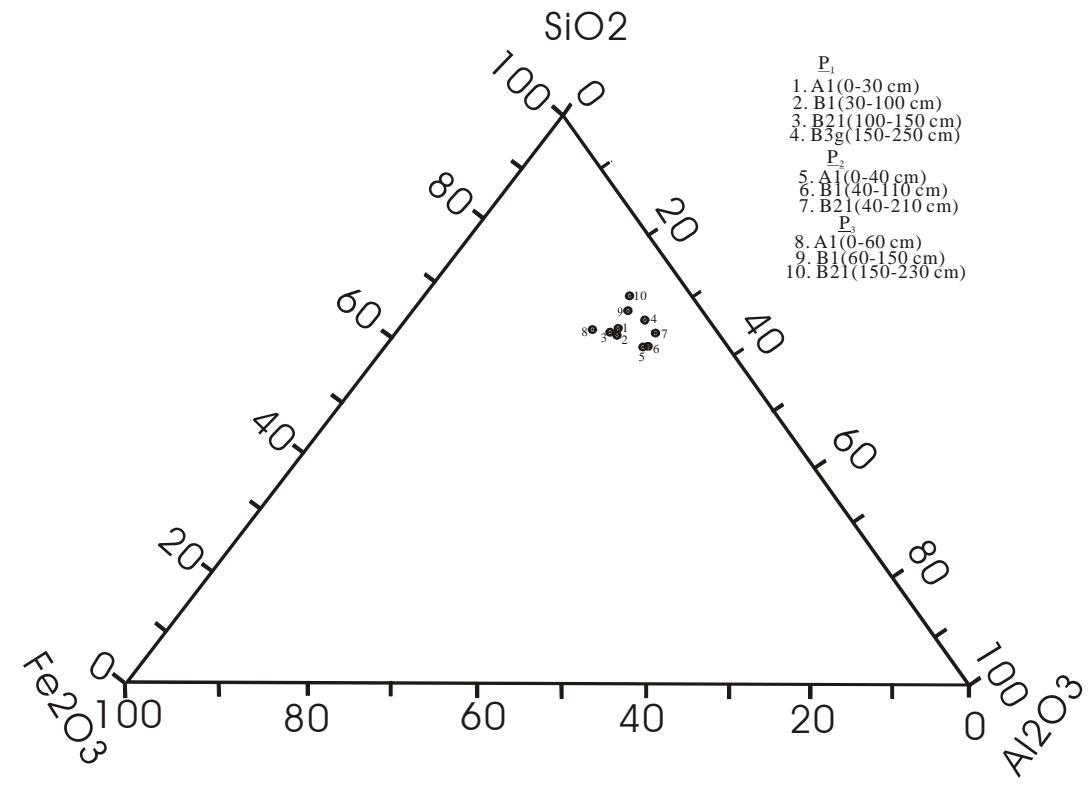

Fig. (9). Location of different horizon samples of profiles $\mathrm{P}_{1}, \mathrm{P}_{2}$ and $\mathrm{P}_{3}$ on the $\mathrm{SiO}_{2}-\mathrm{Al}_{2} \mathrm{O}_{3}-\mathrm{Fe}_{2} \mathrm{O}_{3}$ triangular diagram.

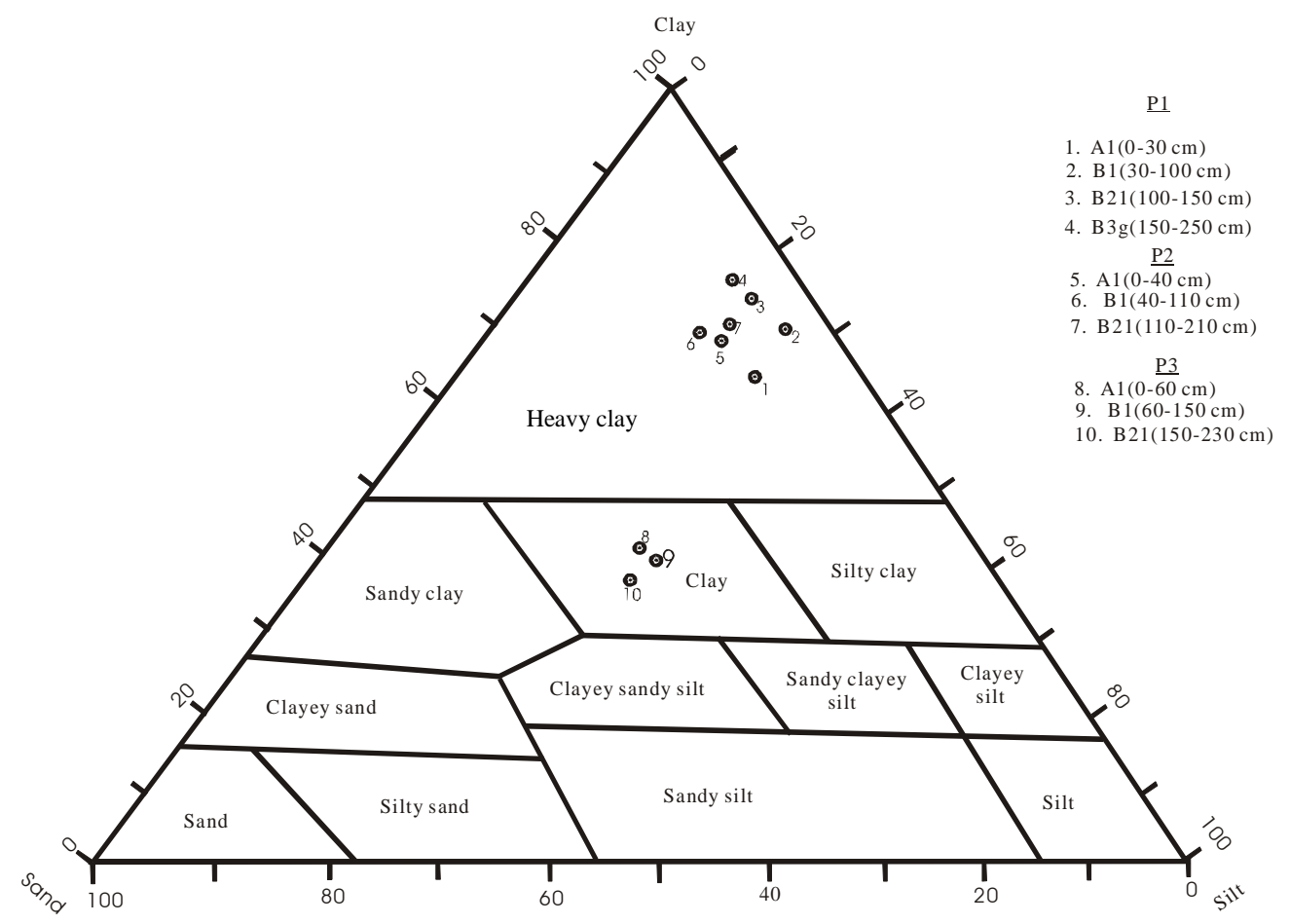

Fig. (10). Soil textural classes with reference to Jamagne's triangle [55].

jig-saw manner. The plastic limits oscillated between 10 and $17 \%$. Consequently, the plasticity indices were very high for all the vertisols and increased with depth (Table 7). The shrinkage limits generally varied between 8.35 and 12.88 , and increased with depth except in Garoua Brasseries where they evolved irregularly with depth (Table 7). These shrinkage values are in the range of poor to medium good quality materials [52]. The activity of the material fluctuated between 0.34 and 0.44 . The activity globally increased with depth, except in Garoua Brasseries where there was an irregular fluctuation (Table 7). The compression limits varied between 0.1164 and 0.2304 (Table 8). The group index globally ranged between 10 and 16 for all the sites (Table 8). The values increased with depth for Poumpoumré and Bounguel but fluctuated irregularly in Garoua vertisols. The soils were plastic clays with more than $75 \%$ fraction passing through $0.80 \mathrm{~mm}$ sieve (Table 8). They were vulnerable to significant changes in volume from dry to humid states and vice versa. The plastic indices were greater than liquid limit minus 30 and enabled to classify the soils in group A-7-6 (clay soils) according to the American Association for State Highway Officials [56]. 
Table 6. Physico-Chemical Characteristics of the Topomorphic Vertisols from the Benue Floodplain

Profile $\mathbf{P}_{1}$

\begin{tabular}{|c|c|c|c|c|c|c|c|c|c|c|c|c|c|c|c|c|c|c|}
\hline $\begin{array}{l}\text { Properties } \\
\text { Horizon } \\
\text { (Depth) }\end{array}$ & 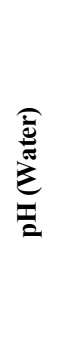 & 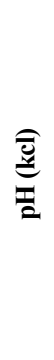 & $\frac{\pi}{2}$ & 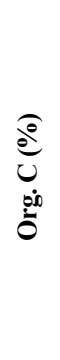 & 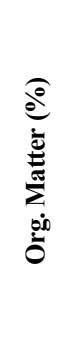 & $\frac{\widehat{e}}{\underline{z}}$ & 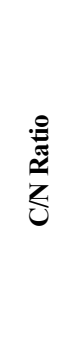 & 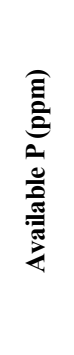 & שี & $\sum^{\infty 0}$ & $\tilde{z}$ & 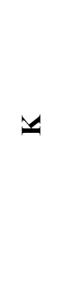 & 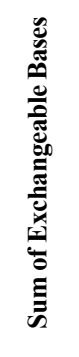 & $\stackrel{\tilde{\theta}}{\tilde{u}}$ & $\begin{array}{l}\frac{\sigma}{e} \\
\frac{5}{\infty}\end{array}$ & 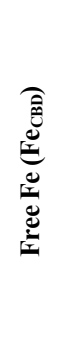 & & 5 \\
\hline $\begin{array}{c}\mathrm{A}_{1} \\
(0-30 \mathrm{~cm})\end{array}$ & 6.2 & 5.3 & 0.9 & 2.62 & 4.50 & 0.10 & 26.20 & 75.53 & 16.11 & 7.11 & 1.78 & 0.98 & 26.00 & 35.00 & 74.30 & 3.47 & 52 & 5.09 \\
\hline $\begin{array}{c}\mathrm{B}_{1} \\
(30-100 \mathrm{~cm})\end{array}$ & 6.6 & 5.3 & 1.3 & 0.36 & 0.62 & 0.02 & 18.00 & 13.91 & 18.58 & 8.98 & 1.03 & 0.40 & 29.00 & 37.00 & 78.40 & 3.75 & 57 & 2.78 \\
\hline
\end{tabular}

Profile $P_{2}$

\begin{tabular}{|c|c|c|c|c|c|c|c|c|c|c|c|c|c|c|c|c|c|c|}
\hline $\begin{array}{l}\text { Properties } \\
\text { Horizon } \\
\text { (Depth) }\end{array}$ & 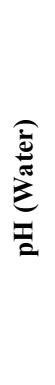 & 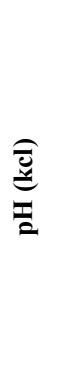 & $\frac{\pi}{2}$ & $\begin{array}{l}\hat{e} \\
0 \\
0 \\
0 \\
0\end{array}$ & 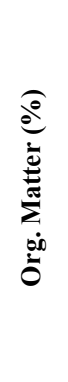 & 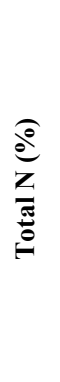 & 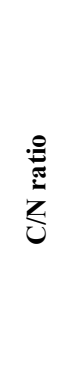 & 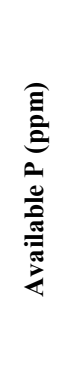 & $\mathrm{Ca}$ & Mg & $\mathbf{N a}$ & $\mathbf{K}$ & 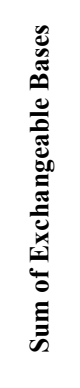 & 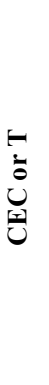 & 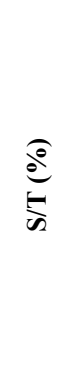 & 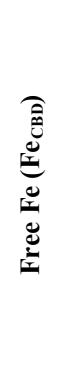 & 苞 & $\frac{5}{z}$ \\
\hline $\begin{array}{c}A_{1} \\
(0-150 \mathrm{~cm})\end{array}$ & 6.4 & 5.2 & 1.2 & 1.62 & 2.82 & 0.09 & 18.00 & 60.40 & 19.68 & 6.90 & 1.15 & 1.17 & 29.43 & 39 & 75.46 & 3.75 & 47 & 2.95 \\
\hline $\begin{array}{c}\mathrm{B}_{1} \\
(40-110 \mathrm{~cm})\end{array}$ & 6.4 & 5.3 & 1.07 & 0.58 & 1.01 & 0.03 & 19.33 & 16.80 & 21.50 & 9.17 & 0.78 & 0.70 & 32.15 & 42 & 76.54 & 3.73 & 49 & 1.85 \\
\hline
\end{tabular}

Profile $P_{3}$

\begin{tabular}{|c|c|c|c|c|c|c|c|c|c|c|c|c|c|c|c|c|c|c|}
\hline \multirow[b]{2}{*}{ Properties } & \multirow[b]{2}{*}{ 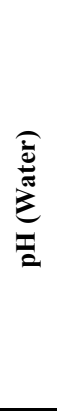 } & \multirow[b]{2}{*}{ 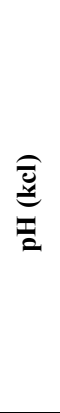 } & \multirow[b]{2}{*}{$\frac{7}{2}$} & \multirow[b]{2}{*}{ 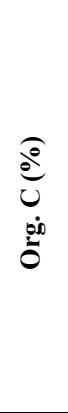 } & \multirow[b]{2}{*}{ 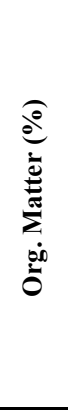 } & \multirow[b]{2}{*}{ 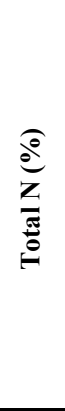 } & \multirow[b]{2}{*}{ 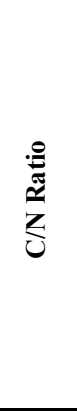 } & \multirow[b]{2}{*}{ 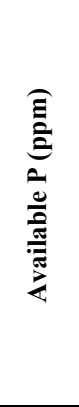 } & \multicolumn{4}{|c|}{ Exchangeable Bases } & \multirow{2}{*}{ 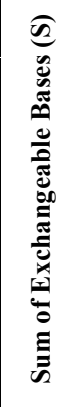 } & \multirow[b]{2}{*}{$\begin{array}{l}\stackrel{t}{0} \\
\dot{0} \\
\text { 둼 }\end{array}$} & \multirow[b]{2}{*}{$\underbrace{\infty}_{\infty}$} & \multirow[b]{2}{*}{ 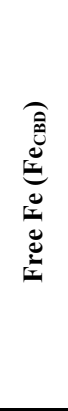 } & \multirow[b]{2}{*}{ 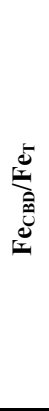 } & \multirow[b]{2}{*}{$\underset{\mathrm{z}}{\mathrm{K}}$} \\
\hline & & & & & & & & & $\tilde{~}$ & $\sum^{\infty 00}$ & $\tilde{z}$ & 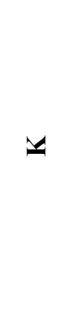 & & & & & & \\
\hline$A_{1}(0-60 \mathrm{~cm})$ & 6.5 & 5.4 & 1.1 & 1.02 & 1.76 & 0.10 & 10.20 & 39.53 & 15.20 & 06.90 & 1.26 & 1.99 & 24.36 & 26.00 & 93.70 & 2.81 & 43 & 4.85 \\
\hline $\mathrm{B}_{1}(60-150 \mathrm{~cm})$ & 6.5 & 5.7 & 0.80 & 0.38 & 0.66 & 0.03 & 13.00 & 18.31 & 15.27 & 07.51 & 1.16 & 0.56 & 24.50 & 28.10 & 87.18 & 2.62 & 47 & 4.14 \\
\hline $\mathrm{B}_{21}(150-2.3 \mathrm{~cm})$ & 7.2 & 6.20 & 1.00 & 0.51 & 0.88 & 0.04 & 22.00 & 13.12 & 22.05 & 08.23 & 1.17 & 0.59 & 32.04 & 34 & 94.23 & 3.47 & 56 & 1.74 \\
\hline
\end{tabular}


Table 7. Mechanical Characteristics of the Topomorphic Vertisols of the Benue Floodplain

Profile $\mathbf{P}_{1}$

\begin{tabular}{|c|c|c|c|c|c|c|c|c|c|}
\hline $\begin{array}{l}\text { Mechanical } \\
\text { (Dorizon } \\
\text { (Depth) }\end{array}$ & $\begin{array}{l}\text { Swelling Rate } \\
\text { in Water (\%) }\end{array}$ & $\begin{array}{c}\text { Swelling Rate in } \\
2 \% \mathrm{Na}_{2} \mathrm{CO}_{3}\end{array}$ & $\begin{array}{c}\text { Liquid } \\
\text { Limit } \\
\text { (Wl) }\end{array}$ & $\begin{array}{c}\text { Plastic } \\
\text { Limit (Wp) }\end{array}$ & $\begin{array}{l}\text { Plasticity } \\
\text { Index (Ip) }\end{array}$ & $\begin{array}{c}\text { Shrinkage } \\
\text { Limit }\end{array}$ & $\begin{array}{l}\text { Shrinkage } \\
\text { Index }\end{array}$ & Activity & $\begin{array}{c}\text { Compression } \\
\text { Limit }\end{array}$ \\
\hline$A_{1}(0-30 \mathrm{~cm})$ & 10.00 & 60.00 & 37.00 & 13.00 & 24.00 & 10.00 & 27 & 0.38 & 0.1728 \\
\hline $\mathrm{B}_{1}(30-100 \mathrm{~cm})$ & 12.00 & 65.00 & 36.00 & 11.00 & 25.00 & 9.00 & 27 & 0.36 & 0.1164 \\
\hline $\mathrm{B}_{3 \mathrm{~g}}(150-250 \mathrm{~cm})$ & 25.00 & 80.00 & 39.00 & 10.00 & 29.00 & 8.35 & 30.65 & 0.39 & 0.1856 \\
\hline
\end{tabular}

Profile $\mathbf{p}_{2}$

\begin{tabular}{|c|c|c|c|c|c|c|c|c|c|}
\hline$A_{1}(0-40 \mathrm{~cm})$ & 14.00 & 70.00 & 39.00 & 16.00 & 23.00 & 11.64 & 27.36 & 0.34 & 0.1856 \\
\hline
\end{tabular}

Profile $\mathbf{P}_{3}$

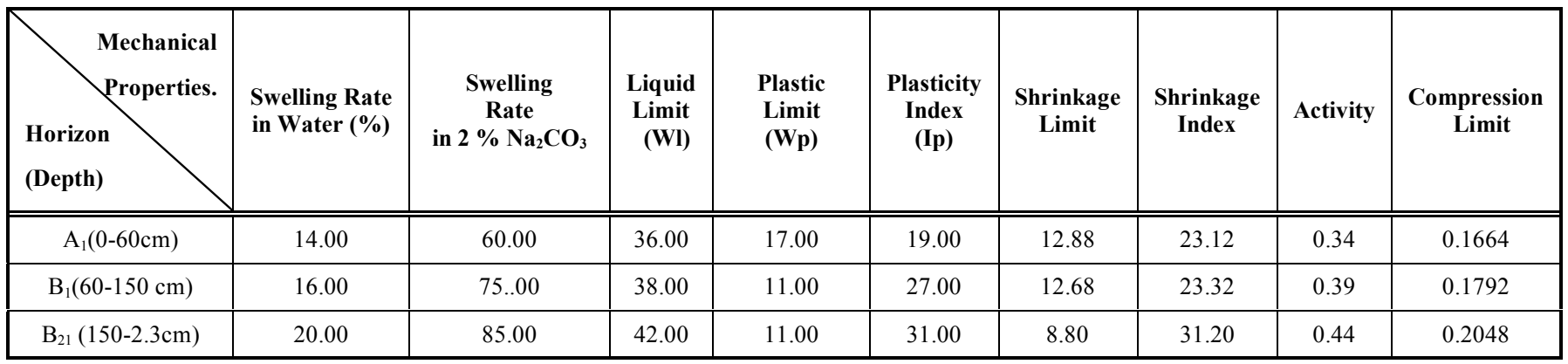

\section{DISCUSSION AND INTERPRETATION}

\subsection{Morphological and Analytical Characteristics}

In the field, the vertisols of the Benue floodplain were water-saturated, ponded and impermeable during the rainy season. During the dry season, they became very dry, extremely hard and presented surficial desiccation cracks and slickensides at the middle parts of their profiles. This behaviour, documented for other topomorphic vertisols in the world, could result from the strongly contrasted tropical climate and to the low topographic position [1-3, 57]. The dark colour (low chroma) could be related to the strong impregnation of the whole profile by organic matter during pedogenesis or to prolong waterlogging $[1,2,57]$. The low chromas are commonly used to predict seasonal variations and are characteristic of hydric soils [57]. The thin profiles, typical of most topomorphic vertisols, might be related to the strongly contrasted climate with a well marked dry season that limits chemical weathering $[18,22,57]$. The low profile differentiation into horizons could be linked to shrink-swell movements that constantly mix the entire profile resulting in homogenisation of texture, structure and dark colour of material $[12,58]$. The heavy clay texture of the studied soils could be associated to the contrasting climate, low topographic position and the alluviation which is the principal process that brings sediments into the lower part of the watershed [2], as confirmed by the results of the heavy mineral and morphoscopic analyses. Moreover, the observable increase in clay contents with depth could be related to slight eluviation-illuviation processes caused by downward movement of water through the soil profiles leading to deposition of clay particles at deeper parts [19]. The higher sandy fraction and lower clay content of the Bounguel vertisols compared to the other studied sites could either be due to a less advanced weathering of primary minerals or to the steeper slope that favour the leaching of 
Table 8. Group Index Determination and Geotechnical Classification of the Topomorphic Vertisols from the Benue Floodplain

Profile $P_{1}$

\begin{tabular}{|c|c|c|c|c|c|c|c|c|c|c|c|}
\hline$A_{1}(0-30 \mathrm{~cm})$ & 91.76 & 37 & 24 & 40 & 40 & 0 & 14 & 14 & 14 & Very bad & A-7-5 \\
\hline $\mathrm{B}_{1}(30-100 \mathrm{~cm})$ & 96.20 & 36 & 25 & 40 & 40 & 0 & 15 & 16 & 15 & Very bad & A-7-5 \\
\hline $\mathrm{B}_{3 \mathrm{~g}}(150-250 \mathrm{~cm})$ & 93.36 & 39 & 29 & 40 & 40 & 0 & 19 & 16 & 16 & Very bad & A-7-5 \\
\hline
\end{tabular}

Profile $\mathbf{P}_{2}$

\begin{tabular}{|c|c|c|c|c|c|c|c|c|c|c|c|}
\hline $\begin{array}{l}\text { Horizon } \\
\text { (Depth) }\end{array}$ & $\begin{array}{c}\text { \% Particle Size } \\
\mathbf{8 8 0 \mu m}\end{array}$ & Wl & Ip & a & b & $\mathbf{c}$ & $\mathbf{d}$ & Ig (Calculated) & Ig (Standard Charts) & Class & A.A.S.S.H.O \\
\hline \hline $\mathrm{A}_{1}(0-40 \mathrm{~cm})$ & 90.03 & 39 & 16 & 40 & 40 & 0 & 6 & 10.60 & 10.50 & Very bad & A-7-5 \\
\hline $\mathrm{B}_{1}(40-110 \mathrm{~cm})$ & 90.13 & 43 & 15 & 40 & 40 & 3 & 5 & 11 & 11 & Very bad & A-7-5 \\
\hline $\mathrm{B}_{21}(110-210 \mathrm{~cm})$ & 95.08 & 46 & 13 & 40 & 40 & 6 & 3 & 11.2 & 11 & Very bad & A-7-5 \\
\hline
\end{tabular}

Profile $\mathbf{P}_{3}$

\begin{tabular}{|c|c|c|c|c|c|c|c|c|c|c|c|}
\hline Parameters & $\begin{array}{c}\% \text { Particle Size } \\
<80 \mu \mathrm{m}\end{array}$ & Wl & Ip & a & b & c & d & Ig (Calculated) & Ig (Standard Charts) & Class & A.A.S.S.H.O \\
\hline $\mathrm{B}_{1}(60-150 \mathrm{~cm})$ & 88.62 & 38 & 11 & 40 & 40 & 0 & 1 & 11 & 9 & Very bad & A-7-5 \\
\hline $\mathrm{B}_{21}(150-2.3 \mathrm{~cm})$ & 88.44 & 42 & 11 & 40 & 40 & 2 & 1 & 10 & 9 & Very bad & A-7-5 \\
\hline
\end{tabular}

Wl: liquid limit; Ip: plasticity index; Ig: group index; a, b, c and d: positive integers that depend on Wl, Ip and \% particle size passing through a < 80 $\mu$ m mesh; A.A.S.S.H.O: American Association for State Highway Officials

clay [2, 57]. The fine sand to coarse sand ratio increased from the base to the surface in all the profiles and could be the result of increased fragmentation of quartz grains attributed to lateral supply of colluvial and alluvial materials from the surrounding high landscapes and the plough action by man [60]. The massive structure, accompanied by a very low porosity, high bulk density and a high compacity of the soils could also be attributed to the heavy clay texture and to the shrink-swell movements that constantly homogenise, densify and compact the soils [5, 22, 23, 61, 62]. The relatively more acidic $\mathrm{pH}$ values recorded for the present study, with respect to literature, could be justified by the absence of limestone in the studied soils as confirmed by the $\mathrm{HCl}$ test. In addition, low $\mathrm{pH}$ could result from the presence of organic acids produced by plant roots, bacteria and fungi as well as from aluminium hydrolysis [57]. The slightly lower trends observed in the Benue floodplain could indicate a slow rate of weathering and soil development in the studied sites in relation to the continuous replenishment of alluvial parent material in this basin landform [62]. The increase in $\mathrm{pH}$ with depth of profile is a characteristic feature of all vertisols and could imply the proximity of the horizons to the parent material $[10,14]$. The insignificant $\mathrm{pH}$ variation among all the soil layers of the different studied sites could be due to a relative homogeneity of the parent rock. The seasonal flooding and the extensive waterlogging might also be contributing to the homogeneity. The occurrence of exchangeable acidity confirmed the presence of exchangable protons and/or aluminium on the absorption complex responsible for the slight acidity [63]. The comparably low organic matter at depth might be due to its homogenisation throughout the profiles as well as the prevailing dry conditions that hinder biomass production and instead amplify the mineralization rate $[28,57,61]$. Also, the low organic matter might be due to continuous cultivation, and this might have a negative impact on soil aggregation and aggregate stability $[29,57]$. The higher organic matter at the surface could be linked to the continuous addition of crop residues on the surface of cropped fields in the area [58]. Moreover, the slight variation in organic matter at the different sites could be explained by variation in periods of flooding, since long flooding periods maintain organic matter wet and so decrease mineralization [2]. Despite a decrease in organic matter with depth, the colour of the studied vertisols, instead darker with depth, could perhaps indicate a higher maturation rate of humic substances at 
depth with a more humid pedoclimate $[57,61]$. The available phosphorus contents were quite close to those of some Ethiopian vertisols but higher than values of more than $70 \%$ of world topomorphic vertisols $[63,64]$. The higher values of total nitrogen and available phosphorus alongside the soil organic matter in surficial horizons and a subsequent decline with depth indicated that the nitrogen and phosphorus were largely associated with soil organic matter which disappeared through rapid decomposition mediated by microbes and abiotic processes [62, 64]. The low total nitrogen and consequently high $\mathrm{C} / \mathrm{N}$ ratio might be related to poor drainage imposed by the heavy clay texture of the vertisols and to the slow transformation of organic matter [57]. The higher concentration of total nitrogen in the upper layers could be due to the presence of immobilised nitrogen in the detritus on the surface, which is prone to microbial decomposition in soil in the subsequent layers. The very high $\mathrm{C} / \mathrm{N}$ was indicative of slow decomposition with lesser mobilization and vice versa [57]. The positive correlation between total nitrogen, organic carbon and available phosphorus was correlated with available recent plant litter whose slow decomposition and mineralization maintained a high $\mathrm{C} / \mathrm{N}$ ratio since carbon is trapped in the profile. The low $\mathrm{C} / \mathrm{N}$ ratio at Bounguel could be related to the steeper slope which enhances better drainage conditions favourable for organic matter decomposition by microbial activity and other abiotic processes. The cation exchange capacity was very high and perhaps correlated with the high smectite contents imposed by low topography, strongly contrasted climate and the presence of a clay-rich alluvial parent rock [18, 62]. Those high values indicated high fertility potentials since high cation exchange capacity implies the capacity to retain nutrients of added fertilizers [62]. Base saturation was high and confirmed that the absorption complex was highly saturated with exchangeable bases; the incomplete base saturation values, revealed the presence of exchangeable $\mathrm{H}^{+}$ and/or $\mathrm{Al}^{3+}$ responsible for low $\mathrm{pH}$ of those vertisols [63]. The high base saturation was related to the low topographic position and the contrasted tropical climate with a well marked dry season; those factors are favourable for the synthesis and conservation of smectite which is the main colloid responsible for cation adsorption in vertisols [62]. The low exchangeable sodium potential $(\mathrm{Na} / \mathrm{T})$ revealed that the studied soils were non-saline; this characteristic might be related to the very dilute underground water resource [43].

The microfabric of the surface horizons, with isotic (aseptic) plasmas, was shaded by their relatively higher organic matter contents [65]. At depth, the presence of birefringent plasmas was accompanied by numerous stress cutans that mainly followed voids (vosepic plasmas); these stress cutans could be related to perturbation or mixing of the profile by vertic movements which manifest by the individualization of slickensides in the middle part of the profile where this phenomenon is most pronounced [65].

The high liquid limits and low plastic limits of the vertisols amplify the plasticity index interval. The very low shrinkage limits and together with the high plasticity indices enabled to qualify those soils as medium to high plasticity inorganic clays $[4,56]$. This indicated a low resistance to tangential stress and a high compressivity as already reported by Ekodeck for some vertisols of North Cameroon [4]. Besides, the compression indices were between the interval of very compressible materials typical of very poor building and foundation infilling materials $[4,56]$. The plasticity indices were directly proportional to the clay contents of the vertisols, implying that the humidity interval for which those soils are plastic increases with clay content, consequently their mechanical resistance was proportional to their texture and humidity [4]. The texture and humidity could therefore be very important parameters to determine suitable plough periods of topomorphic vertisols in order to avoid excessively plastic materials that adhere to farm tools or extremely hard ones that are difficult to break [57]. The group indices enabled to classify the vertisols of the Benue floodplain as very bad materials not recommended as building materials and road layering in their natural state [26, $27,52]$. The activity values of the studied vertisols were very low compared to those of pure sodic smectite (7.2) and calcic smectite (1.5), but very close to the poles of non-swelling minerals [4]. The non-swelling minerals present in those vertisols could be responsible for the observable decrease in activity [25]. In addition, there was a remarkable difference in swelling rate of about four to six folds between samples measured in water and those measured in $2 \% \mathrm{Na}_{2} \mathrm{CO}_{3}$ solution. This indicated that the smectite in the vertisols of the Benue floodplain was a calcic smectite as confirmed by the base saturation data where calcium constituted the predominant exchangeable base. The noticeable increase in swelling rate of the materials when they were treated with $2 \% \mathrm{Na}_{2} \mathrm{CO}_{3}$ could result from the substitution of $\mathrm{Ca}^{2+}$ by $\mathrm{Na}^{+}$in the interlayer space of the smectite to form a sodic smectite which has a higher swelling rate [4]. Also, they were vulnerable to significant changes in volume from dry to humid states and vice versa. Plasticity index for all the studied soils enabled to classify them as A-7-6 (clay soils) according to the American Association for State Highway Officials [56].

Mineralogically, the smectite clay mineral was responsible for the extensive swelling and shrinking upon drying and wetting, the major characteristic of all vertisols $[1,57,62]$. The high smectite content was related to the low landscape positions, a strongly contrasted climate and the presence of a clay-rich alluvial parent material [8, 9, 14, 57]. The simultaneous occurrence of kaolinite in the vertisol profiles could be related to light and successive variations in drainage conditions $[2,57]$. The mineralogical composition was identical throughout all the profiles, similarly to all topomorphic vertisols in the world [1-6]. The combination of those factors enhanced the relative concentration of alkaline and alkali-earth cations alongside silica favourable to the neoformation and conservation of smectite $[2,7,18]$. The low landscape position of the studied vertisols might have boosted smectite synthesis by heritage from downslope accumulation of some rock-forming silicates and neoformation and/or transformation [57, 66, 67]. The main primary heavy minerals present in the studied soils were of magmatic and metamorphic origin implying that at least part of the alluvial deposits that led to their formation was derived from the weathering, erosion, transportation and deposition of soils and rocks from upper parts of the Benue watershed $[2,18,68]$. Hence, the recent alluvial parent rock already enriched in basic cations and silica is necessary for smectite synthesis [2, 57, 67]. Also, part of the secondary minerals possibly resulted from the erosion and deposition of 
soils from the upper parts of the watershed $[2,20]$. The predominance of angular and sub-angular quartz grains clearly confirmed a short fluvial transportation. The lowest marshy and sloughy level landscapes, where all raw materials removed from the upper part of the basin accumulate, ensured the formation and conservation of the topomorphic vertisols [57]. Internal factors such as the nature of alluvial material could also influence the "in situ" weathering of primary minerals; for instance, certain very soluble minerals might protect others by preferentially undergoing dissolution and saturating the soil solution, thus, reducing its aggressiveness for remaining primary minerals [69]. The other minerals could have resulted from direct transformation of primary minerals within the alluvial deposits and recombination of substances leached from the upper parts of the basin [20]. The various secondary minerals were therefore formed by a complex series of processes imposed by the interaction of geological, geomorphological and environmental factors of the Benue drainage basin. Although the X-ray analysis of profile $\mathrm{P}_{3}$ was not done, its morphological organization and analytical properties, very similar to those of the other profiles, clearly indicated a similar mineralogical composition as profiles $\mathrm{P}_{1}$ and $\mathrm{P}_{2}$.

The very rich geochemical composition of the studied vertisols was marked by a strong accumulation of silicon, aluminium, alkaline and alkali-earth elements in the whole profile. The very high $\mathrm{Si} / \mathrm{Al}$ ratio in all the vertisols profiles was in agreement with the predominance of $2 / 1$ clay minerals, typical of a bisiallitisation process [70-74]. The free iron content of the studied soils and the $\mathrm{Fe}_{\mathrm{CBD}} / \mathrm{Fe}_{\mathrm{T}}$ ratio or "weathering index", generally higher than values documented for other topomorphic vertisols, was in the interval of moderately weathered soils [57]. Alkaline and alkali-earth elements which were uniformly distributed throughout the profiles were probably related to the low topographic position and the strongly contrasted climate which limits leaching rate and moderates lixiviation $[18,57$, 62]. Potassium, the most represented alkaline element in all the profiles, could be related to the occurrence of illite detected by X-ray diffraction [75].

Overall, the studied vertisols of the Benue floodplain showed similar morphological and analytical characteristics due to the similar climate, topography and a homogenous parent rock. When compared with other topomorphic vertisols in the world, both were morphologically and analytically similar, with only some light specificities the like acidic $\mathrm{pH}$, higher available phosphorus and high weathering index (Table 9), imposed probably by the local environmental factors [57].

\subsection{Practical Uses and Management-Related Characteristics}

The main interest on the topomorphic vertisols of North Cameroon emanated from their local availability, accessibility, low exploitation cost and very wide geographic extension $[4,5]$. The presence of smectite highlighted their numerous applications and land use patterns $[1,4,6,7,30$, 31 . Their physical properties (high compacity/low porosity, high coherence, massive and very coarse structure, heavy clay texture, high plasticity/stickiness when wet, extreme hardness when dry) render tillage very difficult both in the rainy and dry seasons $[1,2,7,18,30,58,59]$. This is caused by surface ponding and low permeability in the rainy season as well as strong desiccation leading to the development of desiccation cracks in the dry season $[3,51,59,62]$. All these physical aspects of the vertisols also constitute a hindrance to the penetration of water, air, plant roots and pedofauna $[2$, 7]. The deep surficial desiccation cracks in the dry season might hinder root penetration causing root damage [2]. Low permeability and soil cracking could also be responsible for gully erosion and floods which are major environmental problems in north Cameroon. Because of difficult manual tillage of these soils, the use of oxen-tillage is strongly recommended to achieve greater yields. In contrast, the heavy clay texture, uniformly distributed in the profiles, and surface cracking might favour the infiltration and stocking of the first rain water deep within the profile for plant roots. Also, the horizontal landscape of vertisols could permit the economic improvement of surface water reserves. The absence of a stony horizon and hard crusts renders those soils more productive [7,8]. Their particular mechanical characteristics such as high liquid limits, high plasticity indices, high shrinkage limits, high compressivity and the swelling rates make the studied soils unsuitable for exploitation as building and foundation materials as well as road layering materials $[4,11,26,52-54,56]$. They require the addition of non-vertisolic materials like sand, "tank-silt", quicklime and laterites to amend their shrink-swell behaviour before usage $[1,4]$. Because of shrinking and swelling, the installations of man-made structures as houses, roads, electric poles and other installations on those soils is not advisable since large investments could be needed for maintenance and repair of damaged infrastructure [4]. These local materials are also chemically marked by high cation exchange capacity, high sum of bases, high base saturation, very low salinity and an almost neutral $\mathrm{pH}$; they are therefore very fertile for the cultivation of most arable crops $[60,64,65]$. The very low salinity and high extractable calcium hinders clay dispersion and consequently protect the soils against sheet erosion [13, 57]. However, phosphorus, extractable potassium, organic matter and total nitrogen constitute very limiting plant nutrients in the vertisols of the Benue floodplain to support the growth of many arable plants; the application of corresponding fertilisers is therefore recommended [64]. Smectite was also proven to posses strong anti-acid properties due to its ability to adsorb protons at its surface [76]. The studied vertisols could be medically exploited and purified by enrichment of the smectite content to be used for the treatment of gastric ulcers $[11,76]$. Because of their high cation exchange capacity, they could be recommended as bleaching earth for the discolouration of local materials such as oils in the food industry and sewage in environmental protection $[6,11]$. Overall, the topomorphic vertisols of the Benue floodplain necessitate proper management techniques for a more efficient exploitation and conservation/protection.

\section{CONCLUSION}

The present study was aimed at investigating the petrological and analytical characteristics of topomorphic vertisols from North Cameroon, in order to highlight their particularities as well as to envisage their practical uses and management. From the morphological and physical point of view, the vertisols of the Benue floodplain region are 
Table 9. Comparative Properties Between the Topomorphic Vertisols from the Benue Floodplain and those of Other Regions in the World $[4,5,22,23,30,50,57,62]$

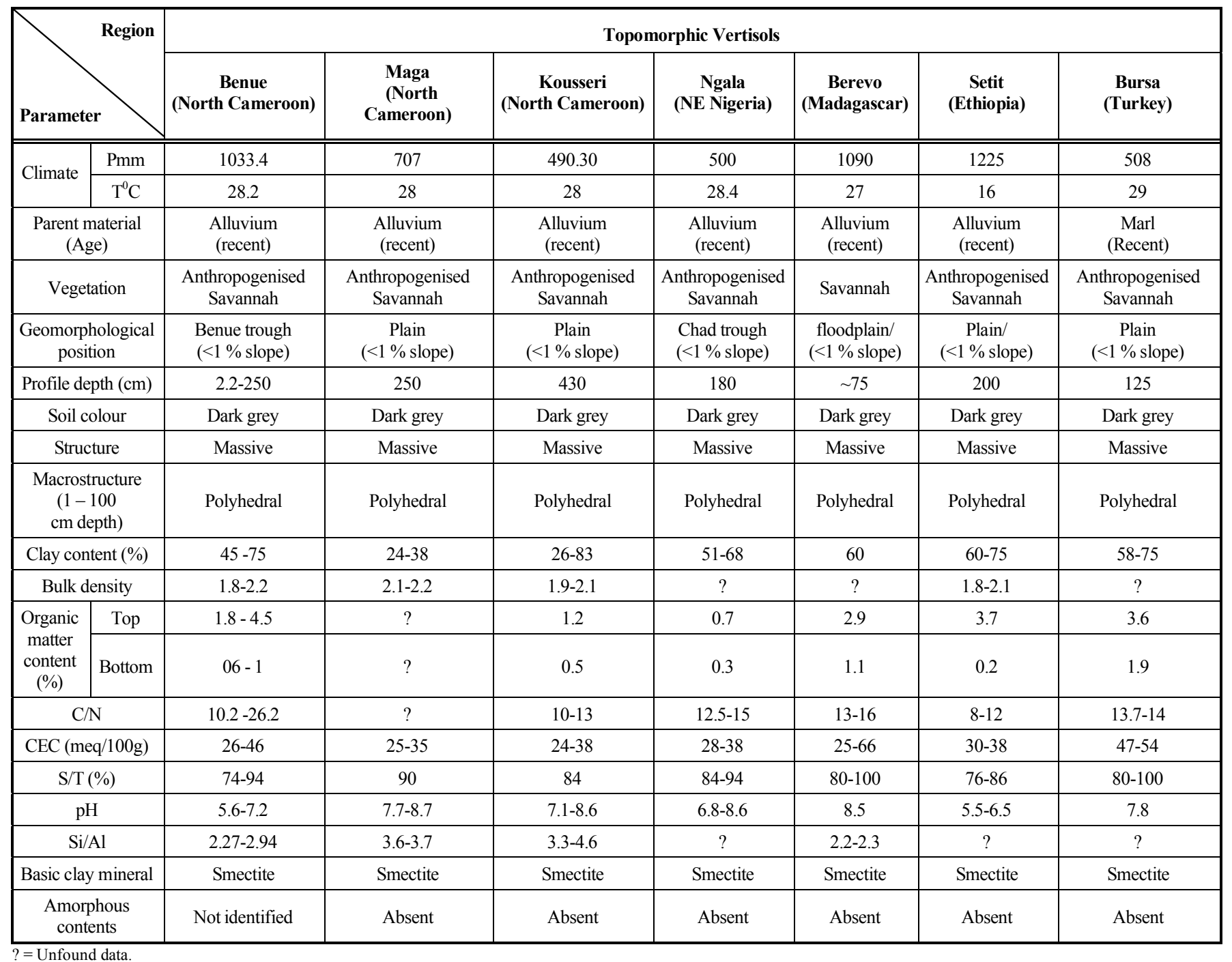

characterised by a dark colour, a heavy clayey texture, a high bulk density, a high compacity, deep wide-opened desiccation cracks at the surface, slickensides at the middle part of the profile and a poor differentiation of their horizons. Physico-chemically, the studied soils are very weakly acidic to slightly basic and poor in organic matter, which is slightly higher in the surface horizon. Cation exchange capacity, sum of exchangeable bases and base saturation are very high. The mechanical analyses reveal high liquid limits, and a low plastic limits, and high plasticity index interval. Those parameters permit to qualify the studied topomorphic vertisols as medium- to high-plasticity inorganic clays. The group index values are very high and enable to classify the studied soils as very bad, not recommended for building, foundation infilling and road layering. The soil microfabric is marked by abundant plasmas, isotic at the surface and birefringent at depth with stress cutans that mainly follow fissural voids. Quartz grains are mainly angular to sub-angular revealing short transportation by water. The microscopic analysis of heavy minerals reveals the presence of magmatic and metamorphic minerals confirming that the alluvial deposits, parent materials of the vertisols, originated from weathering, erosion and deposition of those geological formations from the upper part of the Benue watershed. Mineralogically, the vertisols are mainly constituted by smectite which is responsible for the shrink-swell behaviour of the soils. Geochemically, the studied soils have a homogenous chemical composition throughout the profiles. They are principally alumino-siliceous, characterized by a high $\mathrm{Si} / \mathrm{Al}$ ratio that agrees with the predominance of $2 / 1$ clay minerals in the profile. Moreover, bases occur throughout whole profile, although in smaller amounts, favoured by the low topographic position and the strongly varied climate. Overall, considering their characteristics in majority similar to those of a majority of world topomorphic vertisols, those soils could be potentially useful in many domains like the chemical industry, pharmaceutics, petroleum industry, agronomy or environmental protection. In agriculture, optimum yields could be attained if appropriate management techniques are set up for a more efficient exploitation, protection and conservation of these soils. 


\section{ACKNOWLEDGEMENTS}

The authors duly thank the Reviewers, Prof. Dr. Hardwig E. Frimmel (Julius Maximilians Universität Würzburg), P. G. Silva (Universidad de Salamanca, Spain) and T. Oguchi for their helpful suggestions and critical reviews of the manuscript.

\section{REFERENCES}

[1] FAO, World Base Reference for Soil Resources, Rome: FAO-ISRIC-IUSS, 2006.

[2] M. Gavaud, J.M. Rieffel and J.P. Muller, Ed, Soils of the Benue Valley, from Lagdo to the Confluence of the Faro. Paris: ORSTOM, 1975.

[3] P. Podwojewski, "Gibbsic Vertisols of the New Caledonia in their Pedological Environment", Thèse Doct., Université de Louis-Pasteur, Strasbourg, France, 1992.

[4] G.E. Ekodeck, "Contribution to the Study of the Nature and the Geotechnical Behaviour of the Superficial Swelling Clays of North Cameroon", Thèse Doct. $3^{\text {ème }}$ cycle, Université de Grenoble, Grenoble, France, 1976.

[5] J.P. Nguetnkam, "Clays of Vertisols and Fersiallitic Soils of Far North Cameroon: Genesis, Crystallochemical and Textural Properties, Typology and Application in Vegetable Oil Discolouration", Thèse Doct. d'Etat, University of Yaoundé 1, Yaoundé, Cameroon, 2004.

[6] E.D. Woumfo, A. Elimbi, G. Pancder, R.N. Nyada, and D. Njopwouo, "Physico-chemical and mineralogical characterization of the vertisols from Garoua (North Cameroon)", J. Ann. Chim. Sci. Mat., Vol. 1, pp. 75-90, 2006.

[7] H. Eswaran and T. Cook, "Classification and management-related properties of vertisols" in Proceedings of a Conference held at ILCA on the Management of Vertisols in Sub-Saharan Africa, 1988, pp. 64-84.

[8] M. Raunet, Some Key Morpho-Pedological Aspects of North Cameroon of Use to Agronomists, Montpellier: CIRAD, 2003.

[9] Y. Boulvert, "Some aspects of the influence of topography and parent material on the distribution of ferrallitic, ferruginous and vertisolic soils in the Bossangoa region of North-West Centrafrican Republic", Cah. ORSTOM, Sér. Pédol., Vol. 24, pp. 259-275, 1968.

[10] R. Dudal, Clay Soils of Tropical and Sub-Tropical Regions, Rome, FAO, 2006.

[11] C. Nkoumbou, A. Njoya, D. Njopwouo and R. Wandji, "Economic importance of clay materials", in Proceedings of the First Conference of the Valorisation of Clay Minerals in Cameroon, 2001, pp. 1-12.

[12] B.P. Kfuban Yerima, "Weathering and genesis of volcanic ash-influenced vertisols and vertisol-like soils of El-Salvador", M.S. Thesis, Texas A and M University, Texas, USA, 1983.

[13] C.P.C.S., Soil Classification. Grignon: Ecole Nationale Supérieure d' Agronomie, 1967.

[14] G. Bocquier, Genesis and Evolution of Two Tropical Soil Toposequences in Chad, Geodynamic interpretation, Paris: ORSTOM, 1973.

[15] J. Hervieu and LJ. Nalovic, "Measurement of the trace elements $\mathrm{Co}, \mathrm{Ni}, \mathrm{Cu}, \mathrm{Zn}$ and their distribution of some soil types in Madagascar “, Cah. ORSTOM, Sér. Pédol., Vol. 3, pp. 269-288, 1965.

[16] J. Hervieu, "The quaternary of North Cameroon. Geomorphological evolution model and pedogenetic relationship", Cah. ORSTOM, Sér. Pédol., Vol. 8, pp. 169-173, 1967.

[17] P. Ségalen, "Soils and geomorphology of Cameroon", Cah. ORSTOM, Sér. Pédol., Vol. 5, pp. 137-187, 1976.

[18] M. Gavaud, J.P. Muller and M. Fromaget, "Stages of soil evolution in the alluvial deposits of the Benue valley (North Cameroon)", Cah. ORSTOM, Sér. Pédol., Vol. 14, pp. 321-335, 1976.

[19] M. Gavaud, J.P. Muller and J.M. Rieffel, "Nomenclature rules of soil horizons and pedological features. A first approximation adopted for the mapping of the Benue valley soils in North Cameroon”, Cah. ORSTOM, Sér. Pédol.,Vol. 14, pp. 169-173, 1976.

[20] M. Gavaud and J.P. Muller, "Soil map of Cameroon", in Les Atlas Jeune Afrique, Jeune Afrique, Ed., Paris, 1980, pp. 25-27.
[21] P. Brabant and M. Gavaud, Soils and Land Resources of North Cameroon (North and Far North Provinces), Paris: ORSTOM-MESRES-IRA, 1985.

[22] I.E. Esu and G. Lombin, "Characteristics and management problems of vertisols in the Nigerian Savannah", in Proceedings of a Conference held at ILCA on the Management of Vertisols in Sub-Saharan Africa, 1988, pp. 293-307.

[23] T. Mamo, I. Haque and C.S. Camara, "Phosphorus status of some Ethiopian Highland vertisols", in Proceedings of a Conference held at ILCA on the Management of Vertisols in Sub-Saharan Africa, 1988, pp. 232-249.

[24] L.J. Nalovic, "Study of trace elements and their distribution in some malagasi soils", ORSTOM, Sér. Pédol., Vol. 17, pp. 133-181, 1969.

[25] C. Buhmann and J.L. Schloeman, "Mineralogical characterization of vertisols from the northern regions of the Republic of South Africa", Geoderma, Vol. 66, pp. 239-257, 1995.

[26] LYONS ASSOCIATE Inc., Laterites and lateritic soils and other problem soils of Africa. An engineering study for Agency for International Development AIDS/CAD-2164. Kumasi: Building and Road Research Institute, 1971.

[27] G.E. Ekodeck and S.M. Eno Belinga, "The swelling superficial deposits of North Cameroon: causes and consequences of their geotechnical behaviours", Ann. Fac. Sci., Vol. 21, pp. 39-46, 1977.

[28] J.P. Muller and M. Gavaud, "Conception and realization of an agricultural capability map, case of soil mapping of the Benue valley", Cah. ORSTOM, Sér. Pédol., Vol. 14, pp.161-166, 1976.

[29] M. Ndaka, R. Yongué-Fouateu and P. Bilong, "Influence of Bush fallowing on the pedo-hydric characteristics of the vertisols of Midawa (North Cameroun)", in Proceedings of the First Conference of the Valorization of Clay Minerals in Cameroon, 2001, pp. 247-257.

[30] A. Mvondo Ze, "Major agricultural soils of Cameroon: potentialities and constraints", in Proceedings of a National Forum on the Sustainable Management of Soil Productivity in Cameroon, 2002, pp. 45-65.

[31] R. Kamga, J.P. Nguetnkam and F. Villeras, "Characteristics of North Cameroon clays in view of their use in vegetable oil discoloration", in Proceedings of the First Conference on the Valorization of Clay Minerals in Cameroon, 2001, pp. 247-257.

[32] J.C. Olivry, Rivers and Streams of Cameroon Paris: MESRES-ORSTOM, 1986.

[33] P.M. Etia, "Climate and climatic zones of Cameroon", in Les Atlas Jeune Afrique, Jeune Afrique, Ed., Paris, 1980, pp.16-19.

[34] R. Letouzey, "Phytogeographic map of Cameroon", in Les Atlas Jeune Afrique, Jeune Afrique, Ed., Paris, 1980, pp. 20-24.

[35] S. Morin, "Geomorphological map of Cameroon", in Les Atlas Jeune Afrique, Jeune Afrique, Ed., Paris, 1980, pp. 13-15.

[36] P. Koch, Ed., Reconnaissance geological map. of Cameroon at 1/500.000 scale. Notice of the West- Garoua sheet Yaoundé: Cameroon Geological Mining Division, 1959.

[37] P. Schwoerer, Reconnaissance Geological Map of Cameroon at 1/500.000 Scale. Notice of the East Garoua Sheet, Yaoundé: National Printing Press, 1965.

[38] J. C. Maurin and R. Guiraud, "Relationship between tectonics and sedimentation in the Baremo-Aptian intercontinental basins of Northern Cameroon", J. Afr. Earth Sci., Vol. 10, pp. 47-64.

[39] I. Ngounouno, "Petrology of the Cainozoic magmatism of the Benue valley and the Kapsiki plateau (North Cameroon)", Thèse Doct., Université de Pierre et Marie Curie, Paris, France, 1993.

[40] I. Ngounouno, B. Deruelle, D. Demaiffe and R. Montigny, "New data on the Cainozoic volcanism of the Garoua valley (Upper Benue trough, Northern Cameroon)", J. Acad. Sci., Vol. 325, pp. 87-94, 1997.

[41] C. Moreau, J. M. Regnoult, B. Deruelle and B. Robineau, "A new tectonic model for the Cameroon line, Central Africa", Tectonophysics, Vol. 141, pp. 317-334.

[42] B. Tillement, Ed., Hydrogéology of North-Cameroun Cameroon Geological Mining Division: Yaoundé, 1972.

[43] R. Njitchoua, J.C. Fontes, G.M. Zuppi, J.F. Aranyossi and E. Naah, "Use of Chemical and isotopic tracers in studying the recharge processes of the upper cretaceous aquifer of the Garoua basin, Northern Cameroon", in Proceedings of the Vienne Symposium, 1995, pp. 363-372.

[44] M. Robert and D. Tessier, "Methods of clay preparations for mineralogical studies", Ann. Agron., Vol. 25, pp. 859-882, 1974. 
[45] E.O. McLean, "Soil pH and lime requirement", in Methods of Soil Analysis, Part 2, Chemical and Microbiological Properties, D.R. Buxton, Ed. Madison: American Society of Agronomy Inc. and Soil Science Society of America Inc., 1982, pp. 199-224.

[46] D.W. Nelson and L.E. Sommers, "Total Carbon, Organic Carbon and Organic Matter", In Methods of Soil Analysis, Part 2, Chemical Analysis, D.R. Buxton, Ed. Madison: American Society of Agronomy Inc. and Soil Science Society of America Inc., 1982, pp. 539-579.

[47] J.M. Bremner and C.S. Mulvaney, "Total Nitrogen", in Methods of Soil Analysis, Part 2, Chemical Analysis, D.R. Buxton, Ed. Madison: American Society of Agronomy Inc. and Soil Science Society of America Inc., 1982, pp. 595-624.

[48] S. R. Olsen and L.E. Sommers, "Phosphorus", in Methods of Soil Analysis, Part 2, Chemical and Microbiological Properties 2, A.L. Page, R.H. Buxton, D.R. Miller Keeney, Eds. Madison: American society of Agronomy, 1982, pp. 403-430.

[49] G.W. Thomas, "Exchangeable cations", in Methods of Soil Analysis, Part 2, Chemical and Microbiological Properties, A.L. Page, R.H. Buxton, D.R. Miller Keeney, Eds., Madison: American Society of Agronomy Inc. and Soil Science Society of America Inc., 1982, pp.159-165.

[50] J.D. Rhoades, "Cation exchanges capacity", in Methods of Soil Analysis, Part 2, Chemical and Microbiological Properties 2, A.L. Page, R.H, Buxton, D.R. Miller Keeney, Eds. Madison: American Society of Agronomy, 1982, pp. 149-158.

[51]. SCS, Soil Survey Laboratory Methods and Procedures for Collecting Soil samples Washington, D.C.: U.S. Dep. of Agriculture soil Survey Investigation, 1972.

[52] ASTM, "Classification of soils for engineering purposes", Am. Soc. Test. Mater. Vol.4, pp. 395-408, 1985.

[53] R. D. Holts and W. D. Kovacs, An Introduction to Geotechnical Engineering, Eaglewood Cliffs: Prentice Hall, 1981.

[54] J. Costet and G. Sanglerat, Practical Notes on Soil Mechanics, Paris, Dunod, 1969.

[55] M. Jamagne, "Fundamentals and Techniques of Soil Mapping", Ann. Agron., Vol. 18, pp. 271-414, 1967.

[56] J. Buzon, Laboratory Manual for Laboratory, Highway and In Situ Soil Tests, Paris: Publ. C.E.B.T.P., 1969.

[57] Ph. Duchaufour, Pedogenesis and Classification of Soils, Paris: Masson, 1977.

[58] J. Barrault, J.P. Eckebil and J. Vaille, "The work of IRAT on transplanted sorghum in North Cameroon", Trop. Agronomist, Vol. 27, pp. 791-814, 1972.

[59] C. Seignobos, "Harde and karral of North Cameroun, their perception by the agropastoral populations of the Diamaré", in The Harde Lands: Characterization and Rehabilitation in the Lake Chad Basin, Science Book, CIRAD-Foret: Paris, 1993, pp. 9-28.

[60] J.P. Nguetnkam, P. Bilong, R. Yongué-Fouateu and D. Bitom, "Distribution of particle size fractions-Chemical and mineralogical characteristics within a soil sequence developed on granites in the south Cameroon forestry plateau", in Proceedings of the First Conference on the Valorization of Clay Minerals in Cameroon, 2001, pp. 247-257.

[61] C.E. Coulombe, J.B. Dixon and L.P. Wilding, "Mineralogy and Geochemistry of Vertisols", in Vertisols and Technology for their Management, M. Ahmad, A. Mermut, Eds., Texas: Elsevier Science Publisher, 1996, pp. 115-200,

[62] C. Aydinalp, "Some important properties and classification of vertisols under Mediterranean climate", Afr. J. Agricult. Res., Vol. 6, pp. 449-452, 2010.

[63] Anonymous, Agronomist's Memento, Paris: Rural techniques in Africa, 1993

[64] D. Beyene, "Soil fertility Research on some Ethiopian vertisols", in Proceedings of a Conference Held at ILCA on the management of vertisols in Sub-Saharan Africa, 1988, pp. 223-231.

[65] R. Brewer, Ed., Fabric and Mineral Analysis on Soils, London: Willey and Sons, 1964.

[66] N Kha, "Study of the Evolution of Clay Texture Soils Under Temperate and Tropical Climates", thèse Doct. d' Etat, University de Strasbourg, Strasbourg, France, 1973.

[67] E. Gala'n, "Genesis of clay minerals", in Handbook of Clay Science, F. Bergaya, B.K.G. Theng, G. Lagaly, Eds., Developments in Clay Science, Elsevier, Vol. 1, 2006, pp. 1129-1162.

[68] J. Konta, "Phyllosilicates in rivers: result of weathering, erosion, transportation and deposition", in $11^{\text {th }}$ Scientific meeting of Sociedad Espanõla de Arcillas, 1992, pp. 23-44.

[69] H. Chamayou and J.P. Legros, Eds., Physical, Chemical and Mineralogical Fundamentals of Soil Science, Paris: University Printing Press, 1989.

[70] G. Pédro, "Geochemical characterization attempt of the different zonal processes resulting from superficial weathering", C.R. Acad. Sci., Vol. 262, 1828-1831, 1966.

[71] G. Pédro, "Distribution of the principal types of chemical weathering processes at the surface of the globe", Dyn. Geol. Phys. Geogr. Rev., Vol. 5, 457-470, 1968.

[72] H. Paquet, "Geochemical Evolution of Clay Minerals in Weathering Mantles and Soils under Mediterranean and Tropical Climates", Thèse Doct. d'Etat, Université de Strasbourg, Strasbourg, 1969.

[73] B.P. Ruxton, "Measure of the degree of chemical weathering of rocks", J. Geol., Vol. 76, 518-527, 1968.

[74] J.R. Price and M.A. Velbel, "Chemical weathering indices applied to weathering profiles developed on heterogeneous felsic metamorphic parent rocks", Chem. Geol., Vol. 202, 397-441, 2003.

[75] C.W. Pal, M.K. Wang, W.M. Wang and K.H. Houng, "Smectite in iron-rich calcareous soils and black soils of Taiwan", J. Clay. Miner. Soc. Vol. 47, 389-398, 1999.

[76] C. Banezoue, E.D. Woumfo, D. Njopwouo and R. Wandji, "Antiacid features of some clays consumed by geophagism in Cameroon", in Proceedings of the First Conference on the Valorization of Clay Minerals in Cameroon, 2001, pp. 215-223. 